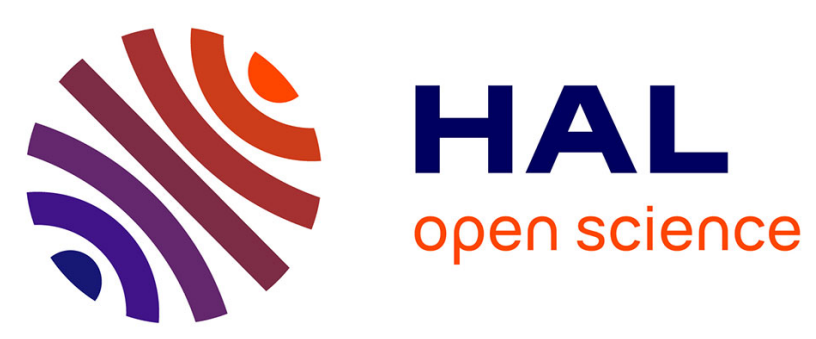

\title{
Holder pasteurization impacts the proteolysis, lipolysis and disintegration of human milk under in vitro dynamic term newborn digestion
}

Samira C. De Oliveira, Amélie Deglaire, Olivia Ménard, Amandine Bellanger, Florence Rousseau, Gwenaele Henry, Emelyne Dirson, Frédéric Carrière, Didier Dupont, Claire Bourlieu

\section{To cite this version:}

Samira C. De Oliveira, Amélie Deglaire, Olivia Ménard, Amandine Bellanger, Florence Rousseau, et al.. Holder pasteurization impacts the proteolysis, lipolysis and disintegration of human milk under in vitro dynamic term newborn digestion. Food Research International, 2016, 88 part B, in press. 10.1016/j.foodres.2015.11.022 . hal-01240472

HAL Id: hal-01240472

https://hal-univ-rennes1.archives-ouvertes.fr/hal-01240472

Submitted on 22 Mar 2016

HAL is a multi-disciplinary open access archive for the deposit and dissemination of scientific research documents, whether they are published or not. The documents may come from teaching and research institutions in France or abroad, or from public or private research centers.
L'archive ouverte pluridisciplinaire HAL, est destinée au dépôt et à la diffusion de documents scientifiques de niveau recherche, publiés ou non, émanant des établissements d'enseignement et de recherche français ou étrangers, des laboratoires publics ou privés. 
Holder pasteurization impacts the proteolysis, lipolysis and disintegration of human milk under in vitro dynamic term newborn digestion.

Samira C. de Oliveira ${ }^{a, b}$, Amélie Deglaire ${ }^{a, b}$, Olivia Ménard ${ }^{a, b}$, Amandine Bellanger $^{c}$, Florence Rousseau $^{\mathrm{a}, \mathrm{b}}$, Gwénaële Henry ${ }^{\mathrm{a}, \mathrm{b}}$, Emelyne Dirson ${ }^{c}$, Frédéric Carrière ${ }^{\mathrm{d}}$, Didier Dupont ${ }^{\mathrm{a}, \mathrm{b}}$, Claire Bourlieu $u^{\mathrm{a}, \mathrm{b} *}$

aINRA, UMR 1253, Science et Technologie du Lait et de I'Oeuf, 65 rue de St Brieuc, 35042 Rennes, France

${ }^{\mathrm{b}}$ Agrocampus Ouest, UMR 1253, Science et Technologie du Lait et de I'Oeuf, 65 rue de St Brieuc, 35042 Rennes, France

${ }^{\text {c} C e n t r e ~ H o s p i t a l i e r ~ U n i v e r s i t a i r e ~ d e ~ R e n n e s, ~ D e ́ p a r t e m e n t ~ d e ~ P e ́ d i a t r i e, ~} 16$ boulevard de Bulgarie, 35203 Rennes, France

${ }^{\mathrm{d} C N R S}$, Aix Marseille Université, UMR7282 Enzymologie Interfaciale \& Physiologie de la Lipolyse, 31 Chemin Joseph Aiguier, 13402 Marseille, France

\section{Abstract}

When the mother's own human milk is unavailable or limited, pasteurized human milk from milk banks is preferentially administered instead of infant formula, especially for vulnerable hospitalized neonates. Holder pasteurization $\left(62.5^{\circ} \mathrm{C}, 30 \mathrm{~min}\right)$ may alter human milk composition and structure, which may modulate its digestive behavior. An in vitro dynamic system was set up to simulate the gastrointestinal digestion of term newborns in order to compare the kinetics of lipolysis, proteolysis and structural disintegration of raw versus pasteurized human milk. Human milk from 5 donors was pooled. Half of the pool was either administrated raw (RHM) or pasteurized (PHM). Digestions were conducted at least in duplicate for RHM and PHM. Heat-induced protein aggregation was observed in PHM. During gastric digestion, $\beta$-casein was proteolyzed significantly faster for PHM than for RHM

Abbreviations: AA, amino acid; CLSM, confocal laser scanning microscopy; DG, diglycerides; FA, fatty acid; FFA, free fatty acid; FID, flame ionization detector; GC, gas chromatography; MG, monoglycerides; PHM, pasteurized human milk; RGE, rabbit gastric extract; RHM, raw human milk; SGF, simulated gastric fluid; SIF, simulated intestinal fluid; sn, stereospecific numbering; SDS, sodium dodecyl sulphate; TG, triglycerides; TLC, thin layer chromatography.

*Corresponding author at: INRA-AGROCAMPUS Ouest, UMR 1253, STLO, 65 rue de St Brieuc, 35042 Rennes, France. Tel.: +332234853 48; fax: +33223485350.

E-mail address: Claire.Bourlieu@rennes.inra.fr (C. Bourlieu). 
$(p<0.05)$, whereas lactoferrin tended to be proteolyzed slower $(p=0.07)$ for PHM. Pasteurization selectively affected the intestinal release of some amino acids. At any time of the gastrointestinal digestion, the lipolysis of PHM was significantly lower than that of RHM, but no impact was observed on the profile of released fatty acids. RHM presented a structural destabilization after 60 min of gastric digestion, while there was no large variation for PHM. In the intestinal phase, the evolution of the particle sizes was rather similar. Overall, Holder pasteurization impacted the proteolysis, lipolysis and disintegration of human milk. However, this impact was limited and the physiologic and metabolic consequences remain to be investigated.

Keywords: Human milk; in vitro dynamic digestion; lipolysis; proteolysis; Holder pasteurization; term newborn

\section{Introduction}

Human milk is the ideal food for infant nutrition, allowing optimal growth and providing several short and long term health benefits (Le Huërou-Luron, Blat, \& Boudry, 2010; Horta, Bahl, Martines \& Victoria, 2007). Numerous human milk components, or their digestive products, are known to play beneficial functions such as the improvement of digestive maturity, the regulation of microbiota development and of the immune system (Donovan, 2006; Labbok, Clark, \& Goldman, 2004; Goldman, 2000). When the mother's own human milk is unavailable or limited, pasteurized human milk from milk banks is preferentially administered instead of infant formulas, especially for vulnerable hospitalized neonates (Wight, 2001). In order to meet the infant nutrient requirements and also to respect the digestive immaturity of the neonates, this practice is more and more encouraged by public health policies and is officially recommended (Arslanoglu et al., 2013; American Academy of Pediatrics, 2012). Several countries (e.g. France, Germany, Australia, Brazil) have developed their own guidelines to implement and regulate human milk banks (Arnold, 2006; Vieira, Soares, Pimenta, Abranches, \& Moreira, 2011). These regulations concern all the steps of handling, processing and storing of human milk, in order to assure its microbiological safety and nutritional quality. For sanitary reasons, the Holder pasteurization $\left(62.5^{\circ} \mathrm{C}, 30 \mathrm{~min}\right)$ of human milk is imposed by the worldwide guidelines. In addition, two cycles of freezing and thawing are applied during milk storage: first from milk expression to pasteurization and last from pasteurization to administration (Borgo, Coelho Araujo, Conceicao, Sabioni, Mendonca, 2014). These physical treatments (pasteurization and freeze-thaw) may partially modify the composition and the structure of the human milk, which could modulate its digestive behavior.

The consequences of pasteurization on the human milk composition have been explored previously, though some points remain unclear. Heating the human milk degrades some 
immunological and nutritional components such as immunoglobulins (IgA, $\lg G$ and $\lg M$ ) (Koenig, de Albuquerque Diniz, Barbosa, \& Vaz, 2005), vitamins (folacin, vitamins C and B6) (Molto-Puigmarti, Permanyer, Castellote, \& Lopez-Sabater, 2011; Vanzoerengrobben, Schrijver, Vandenberg, \& Berger, 1987) and enzymes (lysozyme, lactoperoxidase, lipoprotein lipase, bile salt stimulated lipase) (Akinbi et al., 2010; Henderson, Fay, \& Hamosh, 1998). Besides these alterations, heat treatments together with freeze-thaw cycles of human milk can induce the disruption of the milk fat globules (Vieira et al., 2011; Wardell, Hill, \& Dsouza, 1981), protein denaturation and some aggregation of proteins on the fat globule membrane (Raikos, 2010; Ye, Singh, Taylor, \& Anema, 2004).

In terms of physiological and nutritional impacts, pasteurization of human milk may decrease lipid absorption (Andersson, Savman, Blackberg, \& Hernell, 2007; Thomaz, Goncalves, \& Martinez, 1999; Williamson, Finucane, Ellis, \& Gamsu, 1978) and may reduce the mean weight gain in neonates (Williamson et al., 1978). This may be explained by two main differences. First of all, the two endogenous lipases of human milk that facilitate lipids hydrolysis, lipoprotein lipase and bile salt stimulated lipase (BSSL), are completely inactivated during pasteurization (Blackberg \& Hernell, 1981; Henderson et al., 1998). Secondly, some studies reported important losses of lipids and proteins during the nasogastric tube delivery of pasteurized human milk, which were attributed to increased adherence of the disrupted milk fat globules to flask and tube walls (Stocks, Davies, Allen, \& Sewell, 1985; Vieira et al., 2011). Therefore, these two aspects may impact the energy and nutritional supply, and the ability of infant fed pasteurized human milk to digest lipids (Armand et al., 1996; Lindquist \& Hernell, 2010).

Though the impact of bovine milk emulsion structure on its digestive behavior has been described in vitro (Bourlieu et al., 2015; Golding et al., 2011; Macierzanka, Sancho, Mills, Rigby, \& Mackie, 2009; Singh, Ye, \& Horne, 2009) and in vivo (Armand et al., 1999; Golding et al., 2011), it remains unclear how the biochemical and structural consequences of Holder pasteurization impacts the digestion of the human milk. This understanding could represent a key step to optimize infant nutrition.

Despite its importance, several questions about infant digestion remain unsolved due to ethical and financial constraints of in vivo studies. In order to solve this problem, in vitro dynamic models are relevant tools which take into account the complexity of the physiological digestion and can mimic more realistically the digestive tract conditions and transient states of in vivo infant digestion (Ménard et al., 2014; Shani-Levi, Levi-Tal, \& Lesmes, 2013; Zhang et al., 2014). Moreover, an exhaustive compilation of in vivo digestion data from the literature (Bourlieu et al., 2014) has allowed a pertinent adjustment of parameters of in vitro digestion systems.

The objective of this study was twofold: i) to compare the digestive behavior of raw versus pasteurized human milk having the same macronutrients composition; ii) to set up an in vitro 
dynamic model that simulates the gastrointestinal conditions of a term newborn. More specifically, this study aimed to determine the impact of Holder pasteurization on the kinetics of lipolysis, proteolysis and structural disintegration of human milk in the digestive tract of term newborns.

\section{Materials and methods}

\subsection{Chemicals}

Unless stated otherwise, chemicals were from commercial origin (Sigma-Aldrich, SaintQuentin Fallavier, France).

\subsection{Human milk samples}

Mature human milk samples were obtained from a donor milk bank at the University Hospital Center in Rennes (France). Ethical approval for the study was granted by the Hospitals Ethics Committee $\left(n^{\circ}\right.$ 13-12) and donors gave their informed written consent. Five lactating women collected their milk on average 11 weeks after term delivery (range: 6 to 14 weeks), following the recommendations of the milk bank. On average $( \pm S D)$, donors were $32 \pm 2$ years old and gestational age was $39 \pm 1.5$ weeks. Milk was stored at $-20^{\circ} \mathrm{C}$ after collection.

Human milk was thawed in a $4^{\circ} \mathrm{C}$ temperature controlled room over 16 hours. Equal volumes of milk from each donor were pooled. Half of the pool, called raw human milk (RHM), went back to storage at $-20^{\circ} \mathrm{C}$ until digestion. The other half underwent Holder pasteurization $\left(62.5^{\circ} \mathrm{C}, 30 \mathrm{~min}\right)$ before going back to storage at $-20^{\circ} \mathrm{C}$. The latter pool was called pasteurized human milk (PHM). Macronutrient composition of raw and pasteurized human milk was assessed by infrared spectrophotometry, using a Human Milk Analyzer (Miris, Beledico, Villeurbanne, France) previously validated (Billard et al., 2015). Raw and pasteurized human milk had the same macronutrients composition, which consisted of $26.8 \pm 1.5 \mathrm{~g} / \mathrm{L}$ of fat, $10.7 \pm 0.5 \mathrm{~g} / \mathrm{L}$ of proteins and $79.8 \pm 1.5 \mathrm{~g} / \mathrm{L}$ of carbohydrates.

\subsection{In vitro dynamic digestion model simulating term newborn conditions}

\subsubsection{Digestion conditions}

Gastrointestinal digestions of RHM and PHM were performed in an in vitro dynamic system (DIDGI ${ }^{\circledR}$, INRA, Paris, France) using a digestion model for term newborns. This digestion system has been previously validated against in vivo digestion of infant formula in piglets (Ménard et al., 2014). Parameters for gastric and intestinal phases were based on an exhaustive literature review of in vivo digestive conditions of the infant's upper gastrointestinal tract (Bourlieu et al., 2014). The parameters were chosen to closely mimic the digestive conditions of term newborns fed human milk at the postnatal age of four weeks (Table 1). The in vitro dynamic system was controlled by the 
StoRM ${ }^{\circledR}$ software, which allows regulating and monitoring the digestive parameters (Guillemin, Perret, Picque, Ménard \& Cattenoz, 2010).

The $\mathrm{pH}$ acidification in the gastric compartment followed a linear regression obtained from in vivo data reported mainly for preterm newborns fed human milk or infant formula (Armand et al., 1996; Cavell, 1983; Mason, 1962; Mitchell, McClure, \& Tubman, 2001; Omari \& Davidson, 2003; Roman et al., 2007; Smith, Kaminsky, \& D'Souza, 1986; Sondheimer, Clark, \& Gervaise, 1985), since there is no abundant data from term newborns. The initial $\mathrm{pH}$ was set at the meal $\mathrm{pH}$. Fasted conditions were based on $2 \mathrm{~mL}$ of simulated gastric fluid (SGF) adjusted at $\mathrm{pH} 2.7$, as reported in fasted state for preterm newborn infants fed every 3 hours (Armand et al., 1996; Mitchell et al., 2001; Omari \& Davidson, 2003; Roman et al., 2007; Smith et al., 1986; Sondheimer et al., 1985). Concerning the intestinal compartment, the $\mathrm{pH}$ was constant and fixed at 6.2.

The transit time in the stomach and in the intestine followed an exponential pattern fitted by the mathematical model described by Elashoff et al. (1982). Gastric emptying of human milk was determined by fitting data from Billeaud et al. (1990), where 47 min corresponded to the estimated half-time of emptying $\left(t_{1 / 2}\right)$ of term newborns fed human milk.

Gastric lipase and pepsin amounts were derived from data obtained in preterm newborns (Armand et al., 1996; Roman et al., 2007), assuming that their activities increased with body weight (which is linked to the digestive maturity). The mean body weight of term newborns at four weeks of age was considered $4.25 \mathrm{~kg}$ (WHO, 2006). A freeze-dried rabbit gastric extract (RGE) was employed in the gastric phase, since rabbit gastric lipase is reported to be a relevant option for in vitro gastric digestion studies, presenting $84 \%$ of homology with human gastric lipase (Moreau, Gargouri, Lecat, Junien, \& Verger, 1988; Capolino et al., 2011). RGE was obtained after soaking rabbit stomachs in an appropriate buffer and contained lipase and pepsin. The added amount of RGE, which fully covered the required lipase activity, covered $97.3 \%$ of the pepsin activity required to simulate term newborn gastric digestion (Table 1). RGE was thus the unique source of pepsin. Bovine bile and porcine pancreatin extracts were added to reach the average values reported for term newborns in postprandial intestinal conditions: contents of the bile salts cholic acid and chenodeoxycholic acids for bile (Signer, Murphy, Edkins, \& Anderson, 1974), and lipase activity for porcine pancreatin (Norman, Strandvik, \& Ojamae, 1972). Following the lipase activity, the amounts of trypsin and chymotrypsin added were 148 and $21 \mathrm{U} / \mathrm{mL}$, respectively. The protocols used to determine the bovine bile salts concentration and the enzymes activities have been described by Minekus et al. (2014) in the supplementary material. Concerning the RGE, its lipase activity was measured under standard assay conditions of human gastric lipase $\left(\mathrm{pH} 5.5,37^{\circ} \mathrm{C}\right)$, using tributyrin as substrate (Gargouri et al., 1986).

\subsubsection{Digestion experiment and sampling}


Digestion experiments were performed over three hours, at least in duplicate for each matrix ( $n=2$ for RHM and $n=3$ for PHM). Samples were collected from the human milk (initial time T0) and from both compartments at 30, 60, 90 and $120 \mathrm{~min}$ after the beginning of the digestion. An additional sample was aliquoted at $180 \mathrm{~min}$ from the intestinal compartment. Structural analysis by confocal microscopy and laser light scattering were performed immediately. Aliquots for lipid analysis were immediately submitted to lipid extraction, as detailed in the section 2.6. Other aliquots were frozen at $-20^{\circ} \mathrm{C}$ directly (total fatty acids composition analysis) or after addition of the antiprotease phenylmethylsulfonyl fluoride (PMSF) at $0.37 \mathrm{~g} / \mathrm{L}$ (SDS-PAGE and amino acid analysis).

\subsection{SDS-PAGE}

The electrophoretic analyses were performed using 4-12\% polyacrylamide NuPAGE ${ }^{\circledR}$ Novex $^{\circledR}$ Bis-Tris 15 well precast gels (Invitrogen, Carlsbad, CA, USA), according to the manufacturer's instructions. All samples were diluted 4-fold with NUPAGE ${ }^{\circledR}$ LDS sample buffer and then treated with 0.5 M DL-dithiothreitol and distilled water. Mark 12 Unstained Standard (Invitrogen) was used as a molecular weight $(\mathrm{Mw})$ marker, as reference of the position of the bands. RGE and porcine pancreatin were deposed on the gels as controls, corresponding to the concentrations present in the digestive fluids. Gels were fixed in 30\% (v/v) ethanol, 10\% (v/v) acetic acid and 60\% (v/v) deionized water and were rinsed for $15 \mathrm{~min}$ in deionized water before staining with Coomassie Blue. Image analysis of SDS-PAGE gels was carried out using Image scanner III (GE Healthcare Europe GbmH, Velizy-Villacoublay, France). After digitization of gels, the bands were selected and their gray intensity determined by densitometry using the software Image Quant TL ${ }^{\mathrm{TM}}$ (GE Healthcare Europe GbmH, Velizy-Villacoublay, France). Densitometry analyses of the SDS-PAGE gels were used for semiquantification of protein levels. The percentage of each intact protein remaining in the gastric compartment at a given time was estimated in comparison with the undigested human milk.

\subsection{Amino acid analysis}

The total amino acid (AA) contents were determined after acid hydrolysis of human milk, according to Davies and Thomas (1973). Hydrolysis reaction was done by adding $6 \mathrm{~N}$ hydrochloric acid to $170 \mu \mathrm{L}$ aliquot, at $110^{\circ} \mathrm{C}$ for $24 \mathrm{~h}$ in vacuum sealed glass tubes. The sulfuric AA cysteine and methionine were measured as methionine sulphone and cysteic acid after performic acid oxidation (Moore, 1963). The free AA content was determined after deproteinization of the samples by sulfosalicylic acid (Merck-Eurolab, Grosseron S.A., Saint Herblain, France) according to the method of Mondino et al. (1972). Human milk and digesta aliquots $(1 \mathrm{~mL})$ were treated with $50 \mathrm{mg}$ of sulfosalicylic acid, and incubated for $1 \mathrm{~h}$ at $4^{\circ} \mathrm{C}$. The mixtures were centrifuged at 5,000 $\times \mathrm{g}$ for $15 \mathrm{~min}$ at $4^{\circ} \mathrm{C}$ and the supernatants were filtered through a $0.45 \mu \mathrm{m}$ pore-size membrane (Sartorius, Palaiseau, France). The filtrate was diluted five times with a $0.2 \mathrm{~mol} / \mathrm{L}$ lithium citrate buffer $(\mathrm{pH} 2.2)$ 
before injection. The AA analysis were then carried out by a cation exchange chromatography on a Biochrom 30 automatic AA analyser (Biochrom Ltd, Cambridge, G.B.) according to Moore et al. (1958), using lithium citrate buffers as eluants and ninhydrin post-column reaction system. Tryptophan was not determined. The AA released during digestion was expressed as the percentage level of free AA versus total AA present in the undigested human milk. The level of free AA was expressed in $\mathrm{g} / 100 \mathrm{~g}$ of human milk by dividing the $\mathrm{AA}$ content measured in the digesta by the proportion of human milk in this digesta. This value was determined thanks to the in and out volumes monitoring by the STORM ${ }^{\circledR}$ software.

\subsection{Lipids chemical analysis}

Total lipids (C8:0 to C24:0) were analyzed by gas chromatography coupled to a flame ionization detector (GC-FID) by direct transmethylation in the presence of internal standard (C13) without prior extraction, as described by Lopez-Lopez et al. (2002). The GC-FID conditions of analysis were similar to the one reported by Briard-Bion et al. (2008). Samples were injected in duplicate. The FA methyl esters were identified by comparing the retention time with the standards and their relative contents were expressed as mass $\%$.

The other lipids characterizations (lipid classes and profile in free fatty acids) were done after direct Folch extraction performed immediately after sample collection as described by Bourlieu et al. (2015). The chloroformic phase was recovered and stored at $-20^{\circ} \mathrm{C}$ until further analysis.

The lipid classes, i.e. residual triglycerides (TG), diglycerides (DG), monoglycerides (MG) and free fatty acids (FFA) in aliquots withdrawn from the digestions were analyzed using IATROSCAN MK5 equipment (Iatron Laboratories, Tokyo, Japan), which corresponds to thin-layer chromatography coupled to a FID (TLC-FDI), as previously described (Carriere et al., 2005). The mass detection data were converted into moles by using the average molar masses $(\mathrm{g} / \mathrm{mol})$ calculated from the fatty acid (FA) composition of human milk (TG: 832; DG: 585; MG: 339; FFA: 265). The instantaneous lipolysis degree during digestion was then expressed as the percentage level of FFA (in moles) versus the total acyl chains present in residual glycerides and FFA quantified at a given time, as the following equation:

$$
L D=\frac{100 *[F F A]}{(3 *[T G]+2 *[D G]+[M G]+[F F A])}
$$

With $L D$ lipolysis degree in \%, [FFA], [TG], [DG] and [MG] respectively the free fatty acids, triglycerides, diglycerides and monoglycerides molar concentration (mol/L).

FFA (C8:0 to C20:0) were analyzed after solid phase extraction by GC, using three internal standards (160 $\mu \mathrm{L}$ of $\mathrm{C} 5, \mathrm{C} 11$ and $\mathrm{C} 17$ at $0.5 \mathrm{mg} / \mathrm{mL}$ ) added to aliquot prior solvent extraction, as previously described by Bourlieu et al. (2012). Samples were injected in triplicate. The relative 
contents of each FFA were expressed as mass \%; or converted into moles and reported to the total acyl chains in human milk in order to calculate the lipolysis degree of the undigested human milk.

\subsection{Structural characterization}

The microstructure of human milk and digestas was observed using two apparatus, as previously described by Bourlieu et al. (2015): i) a Nikon C1Si confocal laser scanning microscopy (CLSM) on inverted microscope TE2000-E (Nikon, Champigny-sur-Marne, France), using three fluorescent dyes; ii) a Mastersizer 2000 (Malvern Instruments, Malvern, UK) laser light scattering with two laser sources. Particle size distributions were summarized by distribution curves.

\subsection{Statistical analysis}

The differences between groups during the $3 \mathrm{~h}$ postprandial period were tested by repeatedmeasures analysis of variance using the MIXED procedure with time as repeated factor under the SAS software (SAS 9.4; SAS Institute Inc, Cary, NC). For each parameter, eight different covariance structures for random statements [Unstructured, Compound Symmetry, Heterogenous Compound Symmetry, Auto Regressive (1), Heterogenous Auto Regressive (1), Auto Regressive Moving Average $(1,1)$, Spatial Power and Toeplitz] were tested, and the most appropriate matrix was selected based on the fit statistics (AIC and BICC criterion). Post hoc tests were performed by using contrast analysis. A P-value $<0.05$ was considered as statistically significant. Results were expressed as means \pm standard deviation (SD).

\section{Results}

\subsection{Proteolysis kinetics during human milk digestion}

Fig. 1 shows the protein profiles of RHM and PHM during digestion. The main bands in Fig. $1 \mathrm{~A}$ correspond to lactoferrin, serum albumin, $\beta$-casein and $\alpha$-lactalbumin (theoretical molecular weights of 78, 69, 24 and $14 \mathrm{kDa}$, respectively) (UniProtKB/Swiss-Prot). The decrease observed in band intensity along the digestion was due to proteolysis but also to dilution by digestive secretions and emptying. As secretions output and emptying rate were the same for the two types of milk, the difference of intensities between RHM and PHM were thus interpreted as different proteolysis rates.

As observed in Fig. 1A, the impact of pasteurization on the proteolysis kinetics differed according to the type of protein. Proteolysis of lactoferrin tended to be faster for PHM compared to RHM ( $p=0.07$, Fig. $1 C$ ). In contrast, proteolysis of $\beta$-casein was significantly slower for PHM than for RHM ( $p<0.05$, Fig. 1F). No significant difference was identified between RHM and PHM during the gastric digestion of serum albumin and $\alpha$-lactalbumin (Fig. 1D and 1E). Whatever the type of milk, 
after $120 \mathrm{~min}$ of gastric digestion, lactoferrin and $\beta$-casein were more extensively digested than serum albumin and $\alpha$-lactalbumin (Fig $1 \mathrm{C}$ to $1 \mathrm{~F}$ ).

Regarding the intestinal phase (Fig. 1B), from 30 min onwards no intact protein from human milk was detected, suggesting that proteins were rapidly digested once arriving in the intestinal compartment. Only proteins from porcine pancreatin ( $\mathrm{Mw} \sim 53$ and $24 \mathrm{kDa}$ ) were present in the intestinal compartment at the same ratio throughout the digestion. Peptides arising from the protein digestion were visible in the lower part of the gel ( $\mathrm{Mw} \sim 2$ to $6 \mathrm{kDa}$ ). The peptide profiles largely differed between RHM and PHM at 30 and 60 min, with higher molecular weight peptides observed for RHM.

The AA contents of RHM and PHM before digestion were similar (Table 2). Some AA were present in the free form in RHM and PHM before digestion: in particular, $18.5 \%$ of the total glutamic acid and $3-5 \%$ of the total amount of cysteine, threonine, serine, glycine and alanine. The proportion of nitrogen coming from the total AA analyzed ( $\alpha$-amino nitrogen) before digestion represented $66 \%$ of total nitrogen. Considering the free AA released during gastric digestion, the amounts remained low and similar to the levels reported in the undigested RHM or PHM (data not shown). During the course of the intestinal digestion, the percentage of released AA increased significantly, as displayed in Table 3. Pasteurization affected the intestinal release of some AA, but the effect differed according to the AA. For methionine, proline and glycine, the percentage of released AA was significantly lower for PHM than for RHM during the entire course of the intestinal digestion, and only at 180 min of digestion for glutamic acid. On the contrary, for phenylalanine, tyrosine and isoleucine, the percentage of released AA was significantly higher for PHM than for RHM at some specific time points (Table 3).

\subsection{Lipolysis kinetics and fatty acid composition}

The kinetics of lipolysis of RHM and PHM is showed in Fig. 2. At any time of the gastrointestinal digestion, the lipolysis of PHM was significantly lower than that of RHM $(p<0.05)$. Before digestion, the milk pre-lipolysis was $5 \%$ lower in PHM than in RHM $(p<0.05)$. The lipolysis degree of both RHM and PHM sharply increased during the first 30 min of gastric digestion, and all over the intestinal phase. In contrast, the lipolysis did not evolve that much between 30 and 120 min of gastric digestion: in this compartment, lipolysis levelled off at $16.5 \pm 5 \%$ for PHM and $24.1 \pm 3.2 \%$ for RHM (p<0.05) (Fig. 2A). Higher levels were reached by the end of the intestinal digestion (180 min): $56.4 \pm 3.8 \%$ for PHM versus $62.3 \pm 6.0 \%$ for RHM (Fig. 2 B).

The evolution of the acyl chains (mol \%) from each lipid classes composition of RHM and PHM during the in vitro digestion was linked to the evolution of the lipolysis (Fig. 2C and 2D). The lipid classes composition over gastric phase was quite stable and was marked, as expected, by a 
higher percentage of TG in PHM, and by the early release, i.e. as soon as $30 \mathrm{~min}$, of FFA and DG. The intestinal phase was marked by the progressive decrease of TG and an increase in the products of lipolysis, predominantly FFA along with DG and MG. MG was not detected in the gastric phase, but was observed since the beginning of the intestinal digestion of both RHM and PHM. MG levels were higher in PHM than in RHM from 60 to 120 min.

Fig. 3 shows the acyl chains profile initially esterified in the matrices in comparison with the profile in released FA during the RHM (left panel) and PHM (right panel) in vitro digestions. No impact of pasteurization was observed on the profile of released FA. The pool of mature human milk used in this study contained $46.7 \%$ saturated FA and $53.3 \%$ unsaturated FA. The profile was dominated by five FA: oleic (C18:1 c9, 35.6\%), palmitic (C16:0, 22.8\%), linoleic (C18:2 c9, c12, 9.8\%), stearic (C18:0, 7.5\%) and myristic (C14:0, 6.3\%) acid. The ratio $\omega-6 / \omega-3$ was 9.2. During both gastric and intestinal phases, the major products of the lipolysis were $\mathrm{C} 18: 1 \mathrm{c} 9$ and $\mathrm{C} 16: 0$, followed by $\mathrm{C} 18: 0$ and C18:2 $c 9, c 12$. During the lipolysis, whatever the type of meals, C18:1 $c 9(30.1 \%$ to $49.9 \%)$ and C18:0 (9.8\% to $18.6 \%)$ were selectively released as their relative amount was higher in the released FA fraction than in the total FA initially esterified. On the contrary, the proportion of released C16:0 (15.4 to $26.7 \%$ ) tended to be lower when compared to the total FA initially esterified. During the course of gastric hydrolysis, the proportion of $\mathrm{C} 18: 1$ c9 decreased relative to that of $\mathrm{C} 16: 0$ and $\mathrm{C} 18: 0$.

\subsection{Structural changes during gastric and intestinal digestion}

Concerning the size distribution of the particles, the average mode diameter measured in dissociating agent (sodium dodecyl sulphate, SDS) was higher for PHM $(6.1 \pm 0.1 \mu \mathrm{m})$ than for RHM $(5.1 \pm 0.2 \mu \mathrm{m})$. The specific surface areas developed by the fat globules were $5.0 \pm 1.1$ and $4.0 \pm 0.0$ $\mathrm{m}^{2} / \mathrm{g}$ of lipid in RHM and PHM, respectively. In the same way, microscopic observations showed that pasteurization led to heat-induced protein aggregates in the soluble phase and at the interface of the human milk fat globule membrane (Fig. 4). After $60 \mathrm{~min}$ of gastric digestion, there was a structural destabilization of RHM, with a bimodal distribution of the particles size (Fig. 5A, mode $1=76.5 \mu \mathrm{m}$, mode $2=6.5 \mu \mathrm{m}$ ). The resulting aggregates were dissociated in the presence of SDS, quasi-restoring the initial particle size distribution (data not shown). On the contrary, there were no large variation of the particles size distribution between the start and the end of the gastric digestion of PHM: the average mode diameter was still of $6.5 \mu \mathrm{m}$ at 120 min of gastric digestion (Fig. 5B).

As observed by CLSM, the difference in initial structure was maintained during the gastric phase of digestion, which was dominated by protein aggregation observed from 30 min for both RHM and PHM (Fig. 6A). From 60 up to $120 \mathrm{~min}$ the aggregates were smaller and more homogeneously distributed for PHM compared to RHM, which correspond to the destabilization observed by laser light scattering (Fig. 5A). Less material was observed after prolonged digestion time 
as a result of hydrolysis, emptying and dilution by the gastric fluids. Interestingly, the milk fat globule structure persisted through the gastric digestion: the typical structure characterized by a hydrophobic core and enveloped by an amphiphilic membrane was still observed up to $120 \mathrm{~min}$. At the end of the gastric digestion, these native fat globules were more frequently observed for PHM, whereas for RHM most of globules presented a mix of hydrophobic and amphiphilic compounds in their core. The rafts or micro-domains of the milk fat globule membrane were still visualized even below the protein aggregated layer (Fig. 5C).

In the intestinal phase, the evolution of the particle sizes was rather similar for RHM and PHM (Fig. 5B), with an increase in the mode diameter between 30 and 180 min of intestinal digestion: from $8.1 \pm 1.5$ to $13.2 \pm 1.0 \mu \mathrm{m}$ for RHM, and from $10.3 \pm 0.2$ to $16.2 \pm 1.0 \mu \mathrm{m}$ for PHM. However, in PHM, bigger aggregates (from 150 to $290 \mu \mathrm{m}$ ) were observed at the end of the intestinal phase. CLSM indicated that the intestinal phase was marked by mixed aggregates of apolar and amphiphilic compounds, no proteins in the soluble phase and the quasi-disappearance of previously observed gastric protein aggregates (Fig. 6B).

\section{Discussion}

This study has evidenced that Holder pasteurization affects the digestive disintegration and the kinetics of lipolysis and proteolysis of human milk in term newborns, as investigated using an in vitro dynamic gastrointestinal digestion model. Remarkably, it is the first time that the digestive behavior of raw versus pasteurized human milk having the same macronutrients composition is described. It is also the first time that heat-induced protein aggregation is observed after Holder pasteurization, i.e. a low temperature but long time heat treatment. On the contrary, structural changes in cow's milk proteins after heat treatment with subsequent effects on the emulsion properties were previously described (Raikos, 2010). Heat-induced protein aggregation consists of the aggregation of whey proteins in the colloidal phase, which further form complexes with caseins on the surface of the casein micelle (Guyomarc'h, Law, \& Dalgleish, 2003; Ye, Singh, Taylor, \& Anema, 2002; Ye et al., 2004). From our data, we hypothesize that these structural changes may represent key elements to explain the impact of pasteurization on the gastric proteolysis of $\beta$-casein and lactoferrin.

Lactoferrin in human milk is in the holo conformation, which induces a closed molecule conformation and confers some resistance to proteolysis (Garcia-Montoya, Cendon, ArevaloGallegos, \& Rascon-Cruz, 2012). Its globular structure is likely denatured by pasteurization (Kulmyrzaev, Levieux, \& Dufour, 2005); once denatured and adsorbed at the surface of the micelles, lactoferrin may be more easily digested by proteolytic enzymes. In contrast, $\beta$-casein is sheltered 
inside the casein micelles and consequently less accessible to enzymes after whey protein aggregation. Indeed, other studies raised the hypothesis that heat treatments applied to bovine milk increase the resistance of $\beta$-casein to digestion (Almaas et al., 2006; Dupont et al., 2010). This modified susceptibility to proteolysis for human milk after Holder pasteurization was confirmed in the present study. These observations fit with the mechanism of human milk protein digestion proposed by Zhang et al. (2014), where proteins inside the casein micelle are less accessible for gastric digestion, whereas whey proteins and proteins at the surface of these structures are more accessible.

The absence of intact proteins in the intestinal compartment and the observed appearance of peptides suggest that the proteins emptied from the gastric compartment were rapidly hydrolyzed by the pancreatic proteolytic enzymes. The peptides were observed on the lower part of the gel, but the difference between peptides from RHM or PHM digestion is currently being investigated. Regarding the AA release, pasteurization modulated the bioaccessibility of some AA over intestinal digestion without modifying the total $\alpha$-amino nitrogen released. For both RHM and PHM, a very low percentage of proline was released (2-3\%) during intestinal digestion, which was likely due to the absence in our model of brush border peptidases such as aminopeptidase $\mathrm{N}$ and dipeptidyl peptidase IV (Le Huërou-Luron, 2002). To our knowledge, there is no data about the digestive AA release from human milk in term newborns. Thus, our set of data is crucial to get a better understanding of the human milk protein digestive kinetics, which is directly linked to their metabolic utilization and consequently plays an essential role in early nutrition (Lacroix et al., 2006).

It has been demonstrated that some lipolysis occurs in fresh human milk during refrigeration storage (Bertino et al., 2013; Lavine \& Clark, 1987; Slutzah, Codipilly, Potak, Clark, \& Schanler, 2010), and more extensively after storage at $-20^{\circ} \mathrm{C}$ associated with a freeze-thaw cycle (Bitman, Wood, Mehta, Hamosh, \& Hamosh, 1983). Indeed, Hamosh (1983) reported that BSSL dependency on bile salts was reduced after storage at $-20^{\circ} \mathrm{C}$. The action of endogenous lipases of the human milk is supposed to have positive effect on newborn nutrition since it improves lipid digestion. This natural potential for fat pre-digestion is particularly important in a context of digestive immaturity, in preterms and in the first weeks of life for instance (Pamblanco, Ten, \& Comin, 1987). Hence the prelipolysis of the undigested human milk used in our study is certainly due to the action of endogenous lipases of human milk (i.e. BSSL mainly and lipoprotein lipase) after the storage (until digestion for RHM and until pasteurization for PHM) associated to the freeze-thaw cycles. It should be noted that in our study RHM and PHM were both submitted to two cycles of freeze-thaw (after milk expression and after pasteurization). Considering PHM, we applied exactly the same steps of storage and heat treatment used in human milk banks. Thus, if BSSL is inactivated by heat treatment in pasteurized human milk, it can be active before pasteurization in the presence of low amount of bile salts 
typically reported in human milk (Bourlieu et al., 2014), and contributes to enhance milk fat digestibility.

Pasteurization limited lipolysis in HM before and during digestion. The gastric instantaneous lipolysis levels (18-24\% of total acyl chains) found during RHM gastric digestion are in line with those reported by Roman et al. (2007) for preterm newborns (18-23\% of total acyl chains). It is the first time that the rates of lipolysis are reported for PHM digestion. The inactivation of BSSL by pasteurization of human milk has been reported by various authors (Hamosh, 1983; Hamosh, 1996; Henderson et al., 1998; Lindquist \& Hernell, 2010) and is a key element to explain the observed differences in digestive lipolysis between RHM and PHM. Another complementary effect contributing to this limitation could be the protein aggregation around the milk fat globule membrane induced by pasteurization, which could limit the lipase access to the triglyceride core and delay the lipolysis, as previously suggested (Armand et al., 1996). However, if this was the case, the initial difference in prelipolysis between the two milks would increase at least until the beginning of the intestinal phase, as pancreatic lipase is highly affected by interfacial quality (Bakala N'Goma, Amara, Dridi, Janin, \& Carrière, 2012); this was not observed. The limited impact of the quality of the interface in the gastric phase is in line with recent results from Bourlieu et al. (2015), who demonstrated that the specific surface area of the milk emulsion is a predominant factor, affecting its kinetics of hydrolysis and its disintegration during gastric digestion. In our case, RHM and PHM had similar specific surfaces at the beginning of the digestion. Thus, it suggests that the initial difference in the activity of the BSSL before digestion was the main factor responsible for the more efficient lipid digestion of RHM.

Regarding the lipolysis products, the global evolution of lipid classes was little affected by the pasteurization, which had no impact on the profile of released FA; these results confirmed that the human milk lipid hydrolysis was highly dependent on the lipase specificity. The pre-lipolysis catalyzed by BSSL, which can hydrolyze any of the three positions of the TG, leads to FFA and glycerol release but can transiently generate DG and MG (Lindquist \& Hernell, 2010). Afterwards, the gastric lipase, which is a sn-3 regioselective enzyme, generates mainly sn-1,2 DG and FFA (Bakala N'Goma et al., 2012). The presence of MG in the intestinal phase is in line with the regiospecificity of pancreatic lipase, which hydrolyzes sn-1,3 positions of TG molecules, generating sn-1,2(2,3) DG, sn-(2) MG and FFA (Armand, 2008; Carriere et al., 1997). Also contributing to the intestinal lipolysis, the action of the human milk BSSL (still present in RHM) could be detected on the lipid classes as more MG were detected in PHM compared to RHM from 60 to 120 min of intestinal digestion. It can be explained by the very broad substrate of BSSL specificity and ability to hydrolyze MG in micellar or soluble form liberating glycerol and FFA as final products. The limited activity of BSSL observed in the intestinal phase in vitro is probably not true in vivo, where sn-2 MG and FFA can be progressively absorbed despite limiting bile salt concentrations (Bernback, Blackberg, \& Hernell, 1990). Several in vivo 
studies have underlined the key role of BSSL in favoring fat absorption (Andersson, Hernell, Blackberg, Falt, \& Lindquist, 2011) and clinical trials are being undertaken in Europe and in the United States to examine the effects of additional BSSL in pasteurized human milk (Lonnerdal, 2013).

The increased mode diameter of the milk fat globules in PHM compared to RHM is probably linked to the reorganization of proteins around the milk fat globules, as observed by CLSM. The persistence of native milk fat globules over the gastric digestion is consistent with a partial lipolysis dominated by acid aggregation of the emulsion, and was already demonstrated in vitro in static or semi-dynamic models (Gallier, Ye, \& Singh, 2012; Bourlieu et al., 2015), and in vivo in preterm infants (Armand et al., 1996). Similarly, the greater mix of apolar (TG) and polar compounds (FFA, phospholipids) observed in the core of milk fat globules most for RHM gastric digestion, is in line with the higher extent of lipolysis compared to PHM. The structural instability observed after $60 \mathrm{~min}$ of RHM gastric digestion (and not PHM) did not affect the gap of lipolysis between the two types of meal, probably because lipolysis was already levelling off due to product inhibition (Pafumi et al., 2002). However, the difference in the physical behavior of these two emulsions may affect in vivo the rate of emptying and result in non-homogeneous emptying from the stomach to the intestine. It has been demonstrated (Golding et al., 2011; Marciani et al., 2007) that emulsions that are destabilized in the gastric compartment can lead to the faster emptying of the aqueous phase and consequently to a fat and energy accumulation, modulating the hormonal feedback (cholecystokinin). This may play an important role in the absorption of nutrients in the upper part of the intestine and global nutrient metabolism in infants. These two aspects could not be considered in our dynamic model: the same rate of gastric emptying was used for RHM and PHM (since there are no in vivo data about the rate emptying of pasteurized human milk); moreover, the absorption and hormonal feedback were not simulated.

Newborns present specific differences in the digestion process as compared to older infants or to adults, and term newborns present different digestive maturity compared to preterm (Bourlieu et al., 2014; Dupont et al., 2010; Lindquist \& Hernell, 2010; Shani-Levi et al., 2013). The input parameters proposed here have integrated these specificities since they were based on in vivo data and since some have been additionally validated in in vitro systems (Ménard et al., 2014). Thus, despite some limitations inherent to most in vitro systems, our model appears to be relevant to investigate human milk digestion in the term newborn.

The nutritional impact of different kinetics of liberation of hydrolysis products over the gastrointestinal digestion is ambiguous and has not been studied adequately. In one hand, quick digestion of some proteins may assure earlier bioavailability of nutriments or reduce allergenicity (Cordle, Mahmoud, \& Moore, 1991; Dallas, Underwood, Zivkovic, \& German, 2012). In the other hand, several studies have discussed the beneficial role of conveying intact or partially digested 
bioactive proteins through the gastrointestinal tract (Chatterton et al., 2004; Dallas et al., 2012; Labbok et al., 2004). Notably, lactoferrin and some of its released peptides (i.e. lactoferricin) play multiple beneficial biological properties, i.e. anti-microbial, anti-inflammatory, immunomodulatory, regulatory of neonatal iron absorption (Bellamy, Takase, Wakabayashi, Kawase, \& Tomita, 1992; Garcia-Montoya et al., 2012; Hamosh, 2001; Lonnerdal, 2009). The fact that pasteurization increases lactoferrin gastric hydrolysis could modify its biological activities, in particular by modulating the pattern of the bioactive peptides released. This should be investigated further. The lipolysis products released during human milk digestion are also well-known for their potential positive metabolic impacts. For instance, components such as lysosphingomyelin, sphingosine and medium chain FFA may have antimicrobial and probiotic activities (Bourlieu \& Michalski, 2015). Moreover, long-chain polyunsaturated FA (particularly presents in human milk) play an essential role in infant growth and neural development (Innis, Gilley, \& Werker, 2001).

Several studies have recently underlined the importance of collection and storage conditions on the preservation of the quality of human milk (Borgo et al., 2014; Penn et al., 2014; VazquezRoman, Alonso-Diaz, Garcia-Lara, Escuder-Vieco, \& Pallas-Alonso, 2014). Some authors have proposed alternatives to minimize the side effects of these preservation processes (heat treatment, freeze-thaw cycles) without putting at risk the microbiological safety of the human milk from banks. For instance, Thomaz et al. (1999) proposed that homogenization applied after the pasteurization could reduce the side effects of pasteurization by restoring the lipolysis. More recently, ultravioletirradiation (Christen, Lai, Hartmann, Hartmann, \& Geddes, 2013a; Christen, Lai, Hartmann, Hartmann, \& Geddes, 2013b) and thermosonication (Czank, Simmer, \& Hartmann, 2010) of human milk were proposed as substitute for Holder pasteurization. However, more studies are necessary to determine the impact of each of these technological treatments on the human milk digestion and assimilation.

Though some impacts of pasteurization on the human milk digestive behavior were evidenced in our study, we can globally consider that most beneficial components remain unchanged or little modified by the pasteurization and have protective function for infants (Wight, 2001). In our study for instance, there were similar FA profiles released from PHM or RHM. Infant formulas composition have been largely optimized but cannot provide all the range of bioactive components present in human milk. Indeed, the physical structure of fat droplets and their interfacial composition still differ a lot between human milk and infant formulas (Michalski, Briard, Michel, Tasson, \& Poulain, 2005). These two parameters strongly modulate the efficiency of digestion and nutrients assimilation (Armand et al., 1996; Roman et al., 2007; Ye, Cui, \& Singh, 2010). Therefore, even after pasteurization, the unique composition and demonstrated benefits of human milk makes this complex and evolving biological fluid a good choice for early nutrition (Boyd, Quigley, \& Brocklehurst, 
2007; Schanler, Lau, Hurst, \& Smith, 2005). Moreover, this pasteurized human milk can be fortified to make its nutritional content more adequate to the need of preterm infant.

\section{Conclusion}

The here proposed dynamic in vitro system gives access to parameters hardly accessible in vivo, i.e., the hydrolysis kinetics of lipids and proteins in the gastric and intestinal compartments as well as the concomitant structural changes. The results of this study expand the knowledge and understanding of human milk digestive behaviors, which is important for newborn health and development. Raw human milk is the ideal food for newborns, but pasteurized human milk from milk banks is a possible and well-accepted substitute. In this study, we showed that Holder pasteurization impacts the proteolysis, lipolysis and disintegration of human milk under simulated in vitro dynamic term newborn digestion. However, this impact is limited and its physiologic and metabolic consequences remain unknown. We also underlined the importance of rethinking all the storage processes of human milk in order to optimize the preservation of the milk composition and structure. In the light of the actual knowledge, Holder-pasteurized human milk remains certainly more beneficial than infant formulas for newborns, in particular for preterms. The impact of human milk pasteurization should also be investigated with an in vitro model of preterm digestion as they receive more often pasteurized human milk from banks than term newborns.

\section{Acknowledgements}

The authors warmly thank the volunteer mothers for their donations of breast milk samples and the colleagues from the bank milk of the Rennes University Hospital Center for their involvement in the project. This work was integrated in the COST action FA1005 INFOGEST, and the researchers associated are acknowledged for contribution to the discussion on digestion parameters. The author SCDO acknowledges the PhD scholarship from CNPq (Conselho Nacional de Desenvolvimento Científico e Tecnológico), Brazil.

\section{References}

Akinbi, H., Meinzen-Derr, J., Auer, C., Ma, Y., Pullum, D., Kusano, R. et al. (2010). Alterations in the host defense properties of human milk following prolonged storage or pasteurization. Journal of Pediatric Gastroenterology and Nutrition, 51, 347-352.

Almaas, H., Cases, A. L., Devold, T. G., Holm, H., Langsrud, T., Aabakken, L. et al. (2006). In vitro digestion of bovine and caprine milk by human gastric and duodenal enzymes. International Dairy Journal, 16, 961-968. 
American Academy of Pediatrics (2012). Section on Breastfeeding. Breastfeeding and the use of human milk. Pediatrics, 129, e827-841.

Andersson, E. L., Hernell, O., Blackberg, L., Falt, H., \& Lindquist, S. (2011). BSSL and PLRP2: key enzymes for lipid digestion in the newborn examined using the Caco-2 cell line. Journal of Lipid Research, 52, 1949-1956.

Andersson, Y., Savman, K., Blackberg, L., \& Hernell, O. (2007). Pasteurization of mother's own milk reduces fat absorption and growth in preterm infants. Acta Paediatrica, 96, 1445-1449.

Armand, M. (2008). Milk fat digestibility. Sciences des Aliments, 28, 84-98.

Armand, M., Hamosh, M., Mehta, N. R., Angelus, P. A., Philpott, J. R., Henderson, T. R. et al. (1996). Effect of human milk or formula on gastric function and fat digestion in the premature infant. Pediatric Research, 40, 429-437.

Armand, M., Pasquier, B., Andre, M., Borel, P., Senft, M., Peyrot, J. et al. (1999). Digestion and absorption of 2 fat emulsions with different droplet sizes in the human digestive tract. American Journal of Clinical Nutrition, 70, 1096-1106.

Arnold, L. D. (2006). Global health policies that support the use of banked donor human milk: a human rights issue. International Breastfeeding Journal, 1, 26.

Arslanoglu, S., Corpeleijn, W., Moro, G., Braegger, C., Campoy, C., Colomb, V. et al. (2013). Donor human milk for preterm infants: current evidence and research directions. J.Pediatr.Gastroenterol.Nutr., 57, 535-542.

Bakala N'Goma, J.-C., Amara, S., Dridi, K., Janin, V., \& Carrière, F. (2012). Understanding the lipiddigestion processes in the Gl tract before designing lipid-based drug-delivery systems . Therapeutic Delivery 3[1], 105-124.

Bellamy, W., Takase, M., Wakabayashi, H., Kawase, K., \& Tomita, M. (1992). Antibacterial Spectrum of Lactoferricin-B, A Potent Bactericidal Peptide Derived from the N-Terminal Region of Bovine Lactoferrin. Journal of Applied Bacteriology, 73, 472-479.

Bernback, S., Blackberg, L., \& Hernell, O. (1990). The Complete Digestion of Human-Milk Triacylglycerol Invitro Requires Gastric Lipase, Pancreatic Colipase-Dependent Lipase, and Bile-Salt Stimulated Lipase. Journal of Clinical Investigation, 85, 1221-1226.

Bertino, E., Giribaldi, M., Baro, C., Giancotti, V., Pazzi, M., Peila, C. et al. (2013). Effect of Prolonged Refrigeration on the Lipid Profile, Lipase Activity, and Oxidative Status of Human Milk. Journal of Pediatric Gastroenterology and Nutrition, 56, 390-396.

Billard, H., Simon, L., Desnots, E., Sochard, A., Boscher, C., Riaublanc, A. et al. (2015). Calibration Adjustment of the Mid-infrared Analyzer for an Accurate Determination of the Macronutrient Composition of Human Milk. Journal of Human Lactation (in press). 
Billeaud, C., Guillet, J., \& Sandler, B. (1990). Gastric-Emptying in Infants with Or Without Gastroesophageal Reflux According to the Type of Milk. European Journal of Clinical Nutrition, 44, 577-583.

Bitman, J., Wood, D. L., Mehta, N. R., Hamosh, P., \& Hamosh, M. (1983). Lipolysis of Triglycerides of Human-Milk During Storage at Low-Temperatures - A Note of Caution. Journal of Pediatric Gastroenterology and Nutrition, 2, 521-524.

Blackberg, L. \& Hernell, O. (1981). The bile-salt-stimulated lipase in human milk. Purification and characterization. European Journal of Biochemistry, 116, 221-225.

Borgo, L. A., Coelho Araujo, W. M., Conceicao, M. H., Sabioni, R., I, \& Mendonca, M. A. (2014). Are fat acids of human milk impacted by pasteurization and freezing? Nutrición Hospitalaria, 31, 1386-1393.

Bourlieu, C., Ménard, O., Bouzerzour, K., Mandalari, G., Macierzanka, A., Mackie, A. R. et al. (2014). Specificity of infant digestive conditions: some clues for developing relevant in vitro models. Critical Reviews in Food Science and Nutrition, 54, 1427-1457.

Bourlieu, C. \& Michalski, M. C. (2015). Structure-function relationship of the milk fat globule. Current Opinion in Clinical Nutrition and Metabolic Care, 18, 118-127.

Bourlieu, C., Rousseau, F., Briard-Bion, V., Madec, M. N., \& Bouhallab, S. (2012). Hydrolysis of native milk fat globules by microbial lipases: Mechanisms and modulation of interfacial quality. Food Research International, 49, 533-544.

Bourlieu, C., Ménard, O., De La Chevasnerie, A., Sams, L., Rousseau, F., Madec, M. N. et al. (2015). The structure of infant formulas impacts their lipolysis, proteolysis and disintegration during in vitro gastric digestion. Food Chemistry, 182, 224-235.

Boyd, C. A., Quigley, M. A., \& Brocklehurst, P. (2007). Donor breast milk versus infant formula for preterm infants: systematic review and meta-analysis. Archives of Disease in Childhood Fetal and Neonatal Edition, 92, F169-F175.

Briard-Bion, V., Juaneda, P., Richoux, R., Guichard, E., \& Lopez, C. (2008). trans-C18:1 Isomers in Cheeses Enriched in Unsaturated Fatty Acids and Manufactured with Different Milk Fat Globule Sizes. Journal of Agricultural and Food Chemistry, 56, 9374-9382.

Capolino, P., Guérin, C., Paume, J., Giallo, J., Ballester, J. M., Cavalier, J. F. \& Carrière F. (2011). In Vitro Gastrointestinal Lipolysis: Replacement of Human Digestive Lipases by a Combination of Rabbit Gastric and Porcine Pancreatic Extracts. Food Digestion, 2(1-3), 43-51.

Carriere, F., Grandval, P., Renou, C., Palomba, A., Prieri, F., Giallo, J. et al. (2005). Quantitative study of digestive enzyme secretion and gastrointestinal lipolysis in chronic pancreatitis. Clinical Gastroenterology and Hepatology, 3, 28-38. 
Carriere, F., Rogalska, E., Cudrey, C., Ferrato, F., Laugier, R., \& Verger, R. (1997). In vivo and in vitro studies on the stereoselective hydrolysis of tri- and diglycerides by gastric and pancreatic lipases. Bioorganic \& Medicinal Chemistry, 5, 429-435.

Cavell, B. (1983). Postprandial gastric acid secretion in infants. Acta Paediatr.Scand., 72, 857-860.

Christen, L., Lai, C. T., Hartmann, B., Hartmann, P. E., \& Geddes, D. T. (2013). The Effect of UV-C Pasteurization on Bacteriostatic Properties and Immunological Proteins of Donor Human Milk. Plos One, 8.

Christen, L., Lai, C. T., Hartmann, B., Hartmann, P. E., \& Geddes, D. T. (2013). Ultraviolet-C Irradiation: A Novel Pasteurization Method for Donor Human Milk. Plos One, 8.

Czank, C., Simmer, K., \& Hartmann, P. E. (2010). Simultaneous pasteurization and homogenization of human milk by combining heat and ultrasound: effect on milk quality. Journal of Dairy Research, 77, 183-189.

Davies, M. G. \& Thomas, A. J. (1973). An investigation of hydrolytic techniques for the amino acid analysis of foodstuffs. Journal of the Science of Food and Agriculture, 24, 1525-1540.

Donovan, S. M. (2006). Role of human milk components in gastrointestinal development: Current knowledge and future needs. Journal of Pediatrics, 149, S49-S61.

Dupont, D., Mandalari, G., Molle, D., Jardin, J., Leonil, J., Faulks, R. M. et al. (2010). Comparative resistance of food proteins to adult and infant in vitro digestion models. Molecular Nutrition \& Food Research, 54, 767-780.

Dupont, D., Mandalari, G., Molle, D., Jardin, J., Rolet-Repecaud, O., Duboz, G. et al. (2010). Food processing increases casein resistance to simulated infant digestion. Molecular Nutrition \& Food Research, 54, 1677-1689.

Elashoff, J. D., Reedy, T. J., \& Meyer, J. H. (1982). Analysis of Gastric-Emptying Data. Gastroenterology, 83, 1306-1312.

Gallier, S., Ye, A., \& Singh, H. (2012). Structural changes of bovine milk fat globules during in vitro digestion. Journal of Dairy Science, 95, 3579-3592.

Garcia-Montoya, I. A., Cendon, T. S., Arevalo-Gallegos, S., \& Rascon-Cruz, Q. (2012). Lactoferrin a multiple bioactive protein: An overview. Biochimica et Biophysica Acta-General Subjects, $1820,226-236$

Gargouri, Y., Pieroni, G., Riviere, C., Sauniere, J. F., Lowe, P. A., Sarda, L. et al. (1986). Kinetic assay of human gastric lipase on short- and long-chain triacylglycerol emulsions. Gastroenterology, 91, 919-925.

Golding, M., Wooster, T. J., Day, L., Xu, M., Lundin, L., Keogh, J. et al. (2011). Impact of gastric structuring on the lipolysis of emulsified lipids. Soft Matter, 7, 3513-3523. 
Goldman, A. S. (2000). Modulation of the gastrointestinal tract of infants by human milk, interfaces and interactions. An evolutionary perspective. Journal of Nutrition, 130, 426S-431S.

Guillemin, H., Perret, B., Picque, D., Menard, O., \& Cattenoz, T. (2010). Logiciel StoRM - Stomach and duodenum Regulation and Monitoring. IDDN.FR.001. 230009.000.R.P.2010.000.31235, 290.

Guyomarc'h, F., Law, A. J. R., \& Dalgleish, D. G. (2003). Formation of soluble and micelle-bound protein aggregates in heated milk. Journal of Agricultural and Food Chemistry, 51, 46524660 .

Hamosh, M. (1983). Bile-Salt-Stimulated Lipase of Human-Milk and Fat Digestion in the Preterm Infant. Journal of Pediatric Gastroenterology and Nutrition, 2, S248-S251.

Hamosh, M. (2001). Bioactive factors in human milk. Pediatric Clinics of North America, 48, 69-86.

Hamosh, M. (1983). Bile-Salt-Stimulated Lipase of Human Milk and Fat Digestion in the Preterm Infant. Journal of Pediatric Gastroenterology and Nutrition, 2.

Hamosh, M. (1996). Digestion in the newborn. Neonatal Gastroenterology, 23, 191-209.

Henderson, T. R., Fay, T. N., \& Hamosh, M. (1998). Effect of pasteurization on long chain polyunsaturated fatty acid levels and enzyme activities of human milk. Journal of Pediatrics, $132,876-878$.

Horta B. L, Bahl R., Martines J. C., Victora C. G. (2007). Evidence on the long-term effects of breastfeeding: systematic reviews and meta-analyses. World Health Organization Library Cataloguing-in-Publication Data. http://www.who.int/child_adolescent_health/documents/ 9241595230/en/ (accessed July 2013).

Innis, S. M., Gilley, J., \& Werker, J. (2001). Are human milk long-chain polyunsaturated fatty acids related to visual and neural development in breast-fed term infants? J.Pediatr., 139, 532-538.

Koenig, A., de Albuquerque Diniz, E. M., Barbosa, S. F., \& Vaz, F. A. (2005). Immunologic factors in human milk: the effects of gestational age and pasteurization. Journal of Human Lactation, $21,439-443$.

Kulmyrzaev, A. A., Levieux, D., \& Dufour, E. (2005). Front-face fluorescence spectroscopy allows the characterization of mild heat treatments applied to milk. Relations with the denaturation of milk proteins. Journal of Agricultural and Food Chemistry, 53, 502-507.

Labbok, M. H., Clark, D., \& Goldman, A. S. (2004). Breastfeeding: maintaining an irreplaceable immunological resource. Nature Reviews Immunology, 4, 565-572.

Lacroix, M., Bos, C., Leonil, J., Airinei, G., Luengo, C., Dare, S. et al. (2006). Compared with casein or total milk protein, digestion of milk soluble proteins is too rapid to sustain the anabolic postprandial amino acid requirement. American Journal of Clinical Nutrition, 84, 1070-1079.

Lavine, M. \& Clark, R. M. (1987). Changing Patterns of Free Fatty-Acids in Breast-Milk During Storage. Journal of Pediatric Gastroenterology and Nutrition, 6, 769-774. 
Le Huërou-Luron I. (2002). Production and gene expression of brush border dissaccharidases and peptidases during development in pigs and calves. In R. Zabielski, P. C. Gregory \& B. Weström (Eds.), Biology of the intestine in growing animals (pp. 491-514). London: Elsevier.

Le Huërou-Luron, I., Blat, S., \& Boudry, G. (2010). Breast- v. formula-feeding: impacts on the digestive tract and immediate and long-term health effects. Nutrition Research Reviews, 23, 23-36.

Lindquist, S. \& Hernell, O. (2010). Lipid digestion and absorption in early life: an update. Current Opinion in Clinical Nutrition and Metabolic Care, 13, 314-320.

Lonnerdal, B. (2009). Nutritional roles of lactoferrin. Current Opinion in Clinical Nutrition and Metabolic Care, 12, 293-297.

Lonnerdal, B. (2013). Bioactive proteins in breast milk. Journal of Paediatrics and Child Health, 49, 17.

Lopez-Lopez, A., Lopez-Sabater, M. C., Campoy-Folgoso, C., Rivero-Urgell, M., \& Castellote-Bargallo, A. L. (2002). Fatty acid and sn-2 fatty acid composition in human milk from Granada (Spain) and in infant formulas. European Journal of Clinical Nutrition, 56, 1242-1254.

Macierzanka, A., Sancho, A. I., Mills, E. N. C., Rigby, N. M., \& Mackie, A. R. (2009). Emulsification alters simulated gastrointestinal proteolysis of beta-casein and beta-lactoglobulin. Soft Matter, 5, 538-550.

Marciani, L., Wickham, M., Singh, G., Bush, D., Pick, B., Cox, E. et al. (2007). Enhancement of intragastric acid stability of a fat emulsion meal delays gastric emptying and increases cholecystokinin release and gallbladder contraction. American Journal of PhysiologyGastrointestinal and Liver Physiology, 292, G1607-G1613.

Mason, S. (1962). Some aspects of gastric function in the newborn. Arch.Dis.Child, 37, 387-391.

Ménard, O., Cattenoz, T., Guillemin, H., Souchon, I., Deglaire, A., Dupont, D. et al. (2014). Validation of a new in vitro dynamic system to simulate infant digestion. Food Chemistry, 145, 10391045.

Michalski, M. C., Briard, V., Michel, F., Tasson, F., \& Poulain, P. (2005). Size distribution of fat globules in human colostrum, breast milk, and infant formula. Journal of Dairy Science, 88, 1927-1940.

Minekus, M., Alminger, M., Alvito, P., Ballance, S., Bohn, T., Bourlieu, C. et al. (2014). A standardised static in vitro digestion method suitable for food - an international consensus. Food \& Function, 5, 1113-1124.

Mitchell, D. J., McClure, B. G., \& Tubman, T. R. (2001). Simultaneous monitoring of gastric and oesophageal $\mathrm{pH}$ reveals limitations of conventional oesophageal $\mathrm{pH}$ monitoring in milk fed infants. Archives of Disease in Childhood, 84, 273-276. 
Molto-Puigmarti, C., Permanyer, M., Castellote, A. I., \& Lopez-Sabater, M. C. (2011). Effects of pasteurisation and high-pressure processing on vitamin $\mathrm{C}$, tocopherols and fatty acids in mature human milk. Food Chemistry, 124, 697-702.

Mondino, A., Bongiovanni, G., Fumero, S., \& Rossi, L. (1972). An improved method of plasma deproteination with sulphosalicylic acid for determining amino acids and related compounds. Journal of Chromatography, 74, 255-263.

Moore, S., Spackman, D. H., \& Stein, W. H. (1958). Automatic recording apparatus for use in the chromatography of amino acids. Federation proceedings, 17, 1107-1115.

Moreau, H., Gargouri, Y., Lecat, D., Junien, J. L., \& Verger, R. (1988). Purification, characterization and kinetic properties of the rabbit gastric lipase. Biochimica et Biophysica Acta, 960, 286-293.

Norman, A., Strandvik, B., \& Ojamae, O. (1972). Bile acids and pancreatic enzymes during absorption in the newborn. Acta Paediatr.Scand., 61, 571-576.

Omari, T. I. \& Davidson, G. P. (2003). Multipoint measurement of intragastric pH in healthy preterm infants. Archives of Disease in Childhood - Fetal and Neonatal Edition, 88, F517-F520.

Pafumi, Y., Lairon, D., de la Porte, P. L., Juhel, C., Storch, J., Hamosh, M. et al. (2002). Mechanisms of inhibition of triacylglycerol hydrolysis by human gastric lipase. Journal of Biological Chemistry, 277, 28070-28079.

Pamblanco, M., Ten, A., \& Comin, J. (1987). Bile Salt-Stimulated Lipase Activity in Human Colostrum from Mothers of Infants of Different Gestational-Age and Birth-Weight. Acta Paediatrica Scandinavica, 76, 328-331.

Penn, A. H., Altshuler, A. E., Small, J. W., Taylor, S. F., Dobkins, K. R., \& Schmid-Schonbein, G. W. (2014). Effect of Digestion and Storage of Human Milk on Free Fatty Acid Concentration and Cytotoxicity. Journal of Pediatric Gastroenterology and Nutrition, 59, 365-373.

Raikos, V. (2010). Effect of heat treatment on milk protein functionality at emulsion interfaces. A review. Food Hydrocolloids, 24, 259-265.

Roman, C., Carriere, F., Villeneuve, P., Pina, M., Millet, V., Simeoni, U. et al. (2007). Quantitative and qualitative study of gastric lipolysis in premature infants: do MCT-enriched infant formulas improve fat digestion? Pediatric Research, 61, 83-88.

Schanler, R. J., Lau, C., Hurst, N. M., \& Smith, E. O. (2005). Randomized trial of donor human milk versus preterm formula as substitutes for mothers' own milk in the feeding of extremely premature infants. Pediatrics, 116, 400-406.

Shani-Levi, C., Levi-Tal, S., \& Lesmes, U. (2013). Comparative performance of milk proteins and their emulsions under dynamic in vitro adult and infant gastric digestion. Food Hydrocolloids, 32, 349-357. 
Signer, E., Murphy, G. M., Edkins, S., \& Anderson, C. M. (1974). Role of bile salts in fat malabsorption of premature infants. Archives of Disease in Childhood, 49, 174-180.

Singh, H., Ye, A. Q., \& Horne, D. (2009). Structuring food emulsions in the gastrointestinal tract to modify lipid digestion. Progress in Lipid Research, 48, 92-100.

Slutzah, M., Codipilly, C. N., Potak, D., Clark, R. M., \& Schanler, R. J. (2010). Refrigerator storage of expressed human milk in the neonatal intensive care unit. J.Pediatr., 156, 26-28.

Smith, L. J., Kaminsky, S., \& D'Souza, S. W. (1986). Neonatal fat digestion and lingual lipase. Acta Paediatrica Scandinavica, 75, 913-918.

Sondheimer, J. M., Clark, D. A., \& Gervaise, E. P. (1985). Continuous Gastric Ph Measurement in Young and Older Healthy Preterm Infants Receiving Formula and Clear Liquid Feedings. Journal of Pediatric Gastroenterology and Nutrition, 4, 352-355.

Stocks, R. J., Davies, D. P., Allen, F., \& Sewell, D. (1985). Loss of Breast-Milk Nutrients During TubeFeeding. Archives of Disease in Childhood, 60, 164-166.

Thomaz, A. C. P., Goncalves, A. L., \& Martinez, F. E. (1999). Effects of human milk homogenization on fat absorption in very low birth weight infants. Nutrition Research, 19, 483-492.

Vanzoerengrobben, D., Schrijver, J., Vandenberg, H., \& Berger, H. M. (1987). Human-Milk Vitamin Content After Pasteurization, Storage, Or Tube-Feeding. Archives of Disease in Childhood, 62, 161-165.

Vazquez-Roman, S., Alonso-Diaz, C., Garcia-Lara, N. R., Escuder-Vieco, D., \& Pallas-Alonso, C. R. (2014). Effect of freezing on the "creamatocrit" measurement of the lipid content of human donor milk. Anales de Pediatria, 81, 185-188.

Vieira, A. A., Soares, F. V., Pimenta, H. P., Abranches, A. D., \& Moreira, M. E. (2011). Analysis of the influence of pasteurization, freezing/thawing, and offer processes on human milk's macronutrient concentrations. Early Human Development, 87, 577-580.

Wardell, J. M., Hill, C. M., \& Dsouza, S. W. (1981). Effect of Pasteurization and of Freezing and Thawing Human-Milk on Its Triglyceride Content. Acta Paediatrica Scandinavica, 70, 467-471.

WHO Multicentre Growth Reference Study Group (2006). WHO Child Growth Standards based on length/height, weight and age: Methods and development. Geneva: World Health Organization (312 pages).

Wight, N. E. (2001). Donor human milk for preterm infants. J.Perinatol., 21, 249-254.

Williamson, S., Finucane, E., Ellis, H., \& Gamsu, H. R. (1978). Effect of Heat-Treatment of Human Milk on Absorption of Nitrogen, Fat, Sodium, Calcium, and Phosphorus by Preterm Infants. Archives of Disease in Childhood, 53, 555-563. 
Ye, A., Singh, H., Taylor, M. W., \& Anema, S. (2002). Characterization of protein components of natural and heat-treated milk fat globule membranes. International Dairy Journal, 12, 393402.

Ye, A. Q., Cui, J., \& Singh, H. (2010). Effect of the fat globule membrane on in vitro digestion of milk fat globules with pancreatic lipase. International Dairy Journal, 20, 822-829.

Ye, A. Q., Singh, H., Taylor, M. W., \& Anema, S. (2004). Interactions of whey proteins with milk fat globule membrane proteins during heat treatment of whole milk. Lait, 84, 269-283.

Zhang, Q., Cundiff, J. K., Maria, S. D., McMahon, R. J., Wickham, M. S. J., Faulks, R. M. et al. (2014). Differential Digestion of Human Milk Proteins in a Simulated Stomach Model. Journal of Proteome Research, 13, 1055-1064. 


\section{Figure captions}

Fig. 1. SDS-PAGE protein profiles of RHM and PHM during gastric (A) and intestinal (B) in vitro dynamic digestion simulating term newborn conditions and the corresponding percentage of intact protein during gastric digestion as obtained by densitometry for lactoferrin (LF; panel C), serum albumin (SA; panel D), $\alpha$-lactalbumin ( $\alpha$-Lac; panel E) and $\beta$-casein $(\beta-C N$; panel F). Raw (R) and pasteurized $(P)$ human milk digesta appear side by side on the gels ( $A$ and $B$ ) for each time (left: $R$; right: P). Protein molecular mass standards (S) are on the left. Rabbit gastric extract (RGE) diluted in SGF and porcine pancreatin (Pan) diluted as in SIF are used as extra controls. Data point in panels C,

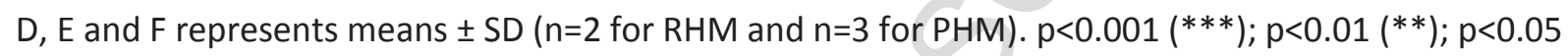
$(*) ; p>0.1(\mathrm{NS})$. Data from undigested milk were not included in the statistical analysis.

Fig. 2. Kinetics of lipolysis of RHM and PHM during gastric (A) and intestinal (B) in vitro dynamic digestion simulating newborn term conditions. The lipolysis degree was determined based on TLCFID for digesta and on gas chromatography for undigested milk. Data point represents means $(n=2$ for RHM and $n=3$ for PHM) \pm SD. $p<0.001\left({ }^{* * *}\right) ; p<0.01\left({ }^{* *}\right) ; p<0.05\left({ }^{*}\right) ; p>0.1$ (NS). The evolution of the lipid classes composition (acyl chains, mol \%) of RHM (C) and PHM (D) during the gastrointestinal digestion was determined by TLC-FID. TG, FFA, DG and MG are respectively triglycerides, free fatty acids, diglycerides and monoglycerides

Fig. 3. Acyl chains profiles initially esterified in human milk compared to free fatty acids released from RHM and PHM during gastric (A) and intestinal (B) in vitro dynamic digestion. Fatty acids were determined by gas chromatography. Data point represents means ( $n=2$ for RHM and $n=3$ for PHM) \pm SD.

Fig. 4. Particles size distributions (as determined by laser light scattering in SDS) and confocal laser scanning microscopy images (x60 zoom 3) of undigested RHM and PHM. Data are mean of two digestions. Proteins are colored in blue (FastGreen ${ }^{\circledR}$ ), apolar lipids in green (Lipidtox ${ }^{\circledR}$ ) and polar lipids in red (Rhodamine-PE $\left.{ }^{\circledR}\right)$. White arrows are pointing at heat-induced protein aggregates in PHM. Scale bars $=10 \mu \mathrm{m}$.

Fig. 5. Particle size distributions of RHM and PHM during gastric (A) and intestinal (B) in vitro dynamic digestion, as determined by laser light scattering in water. Data represents the average of two digestions, each of them being measured in triplicate. 
Fig. 6. Confocal laser scanning microscopy images of RHM and PHM during gastric (A) and intestinal (B) in vitro dynamic digestion. C) Decomposition of the images at 120 min of gastric digestion of RHM and PHM (photo 1: proteins, apolar and polar lipids; photo 2: proteins and polar lipids; photo 3: proteins. Each frame is the average of two observations (x60 zoom 1 to 6). Proteins are colored in blue (FastGreen ${ }^{\circledR}$ ), apolar lipids in green (Lipidtox ${ }^{\circledR}$ ) and polar lipids in red (Rhodamine-PE ${ }^{\circledR}$ ). 


\section{Figure 1}
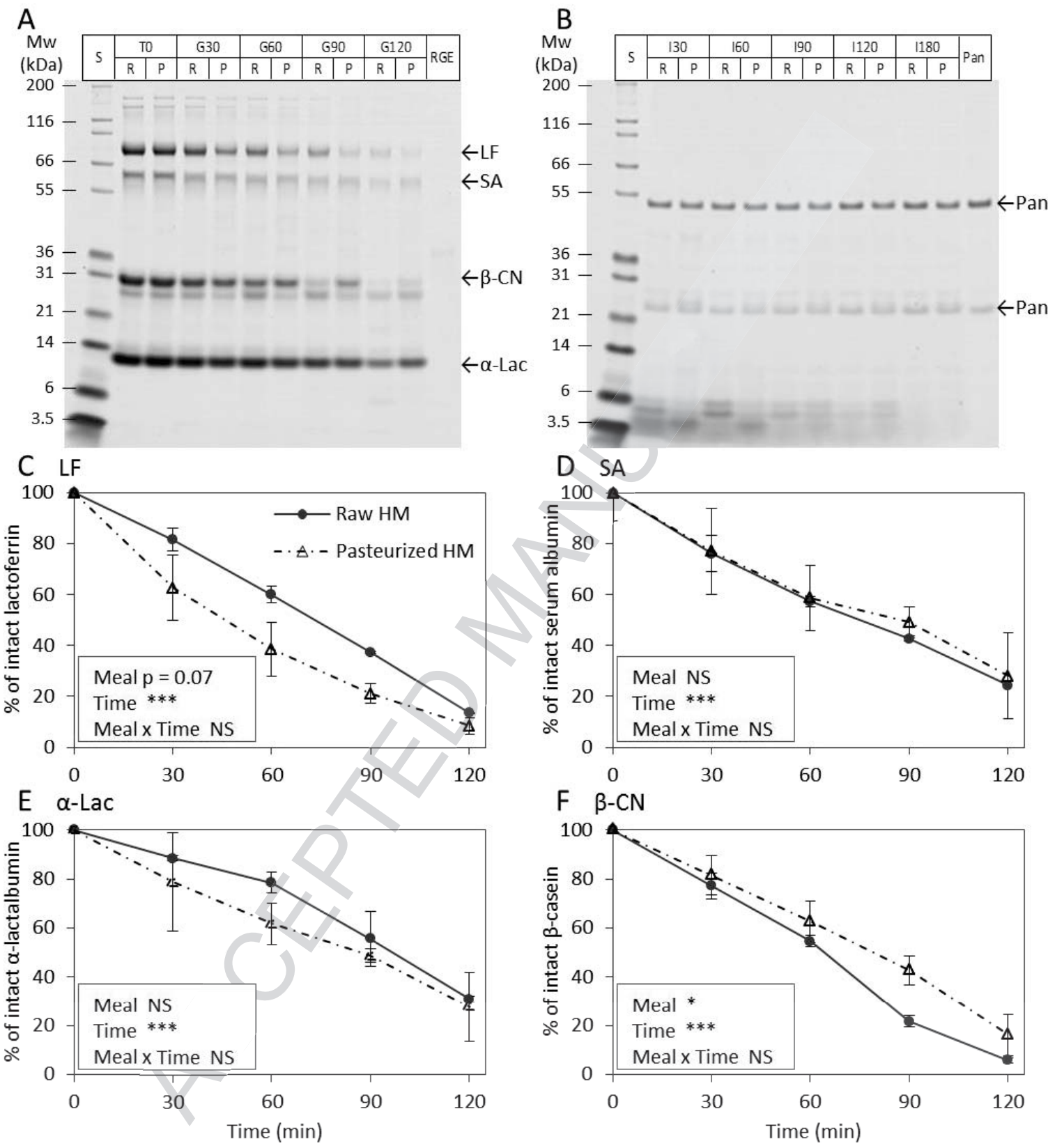


\section{Figure 2}
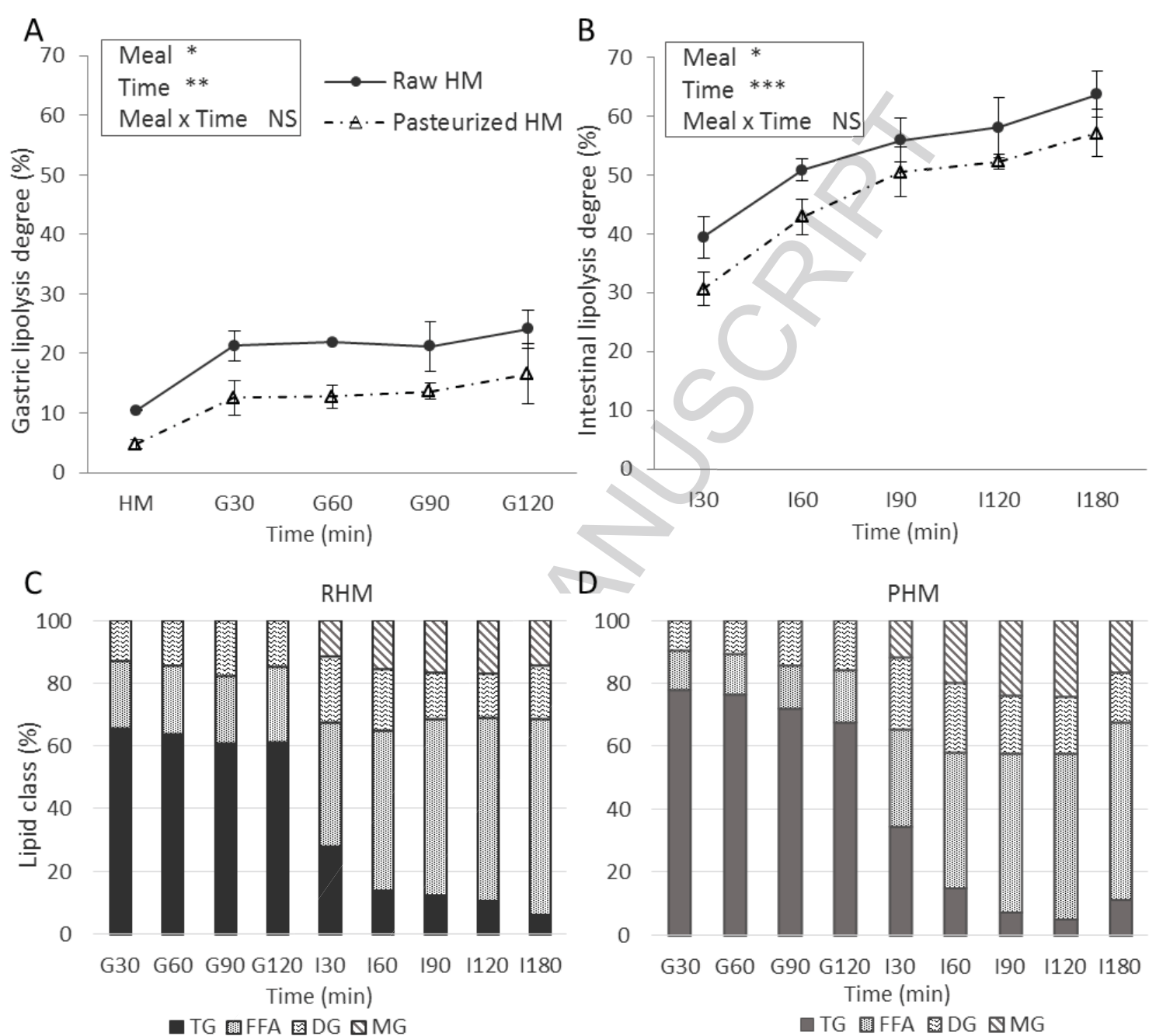


\section{Figure 3}

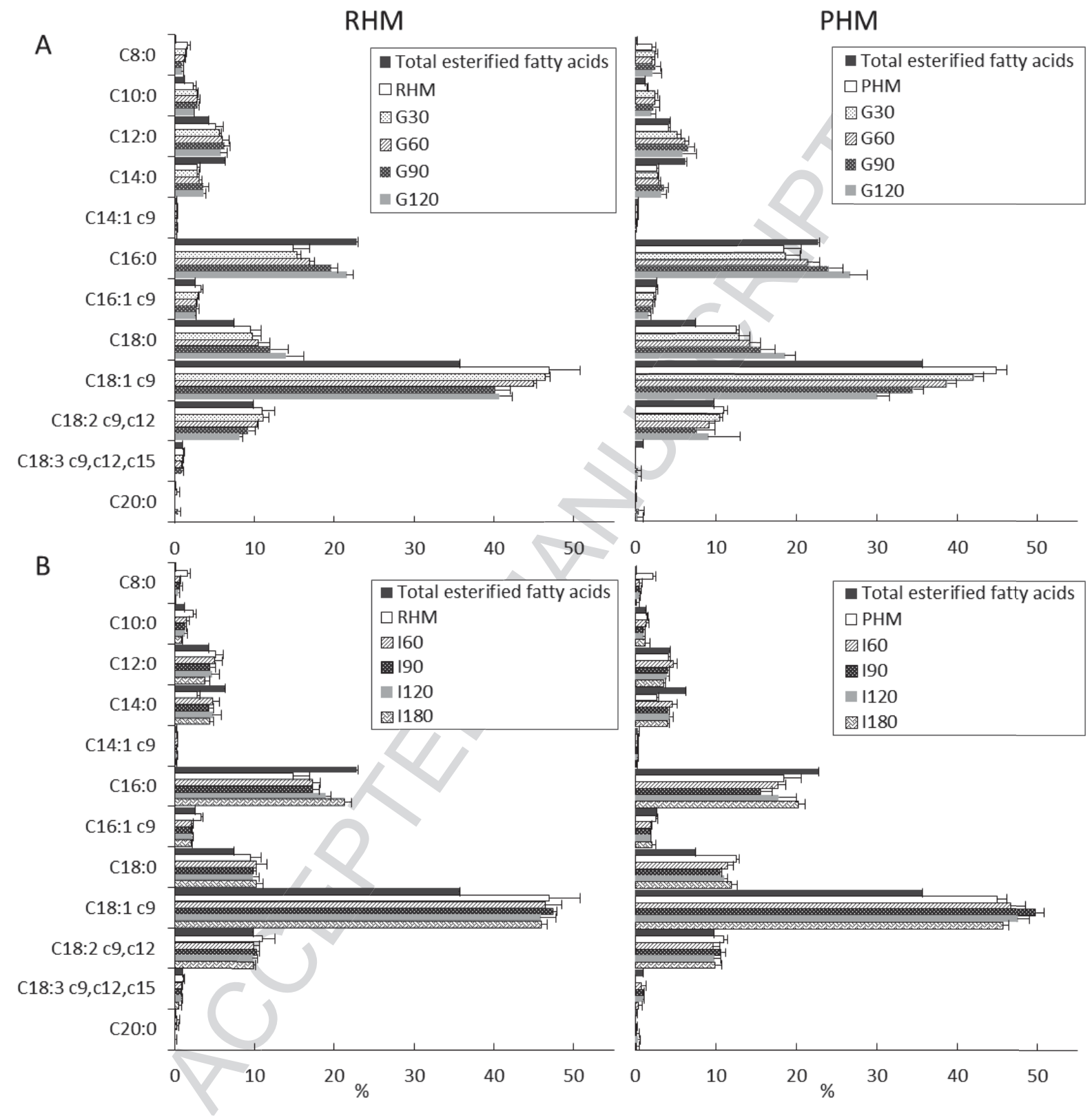


Figure 4

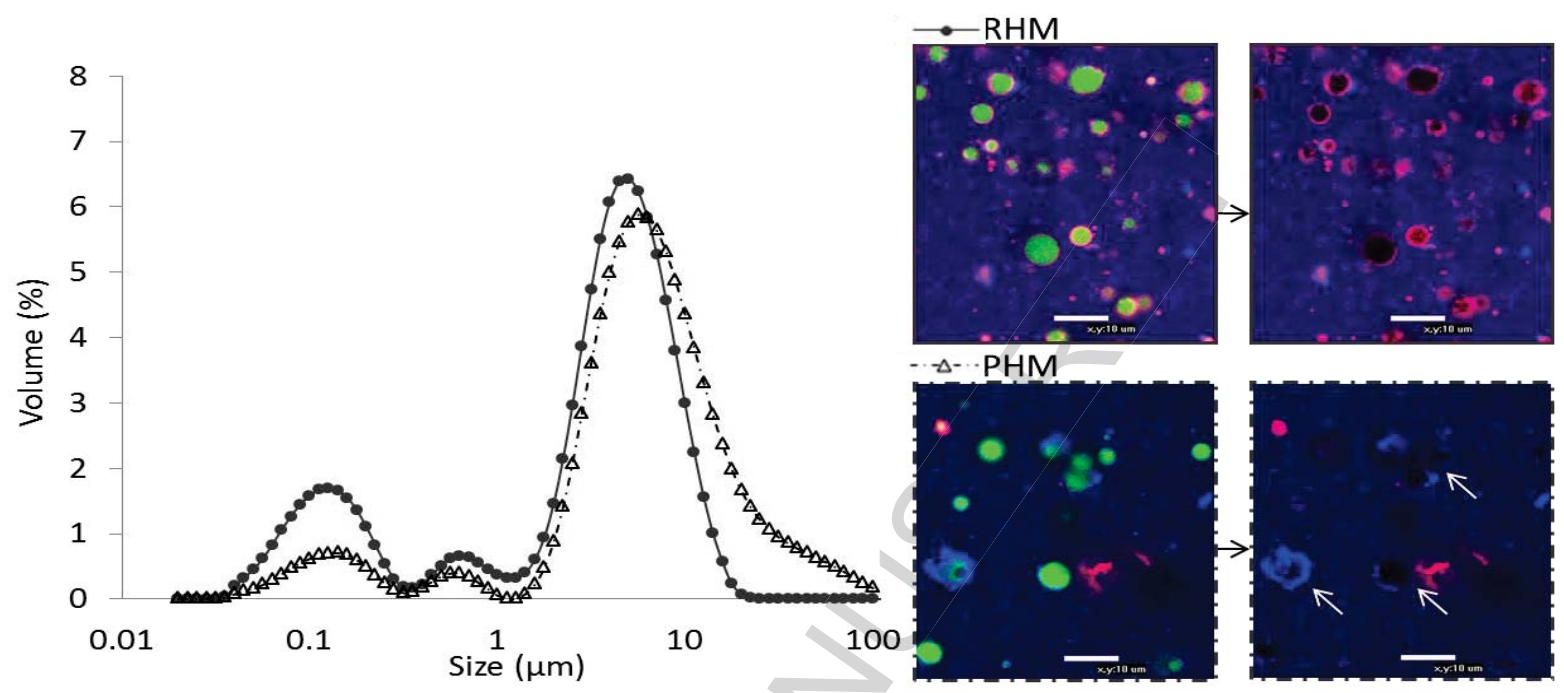




\section{Figure 5}
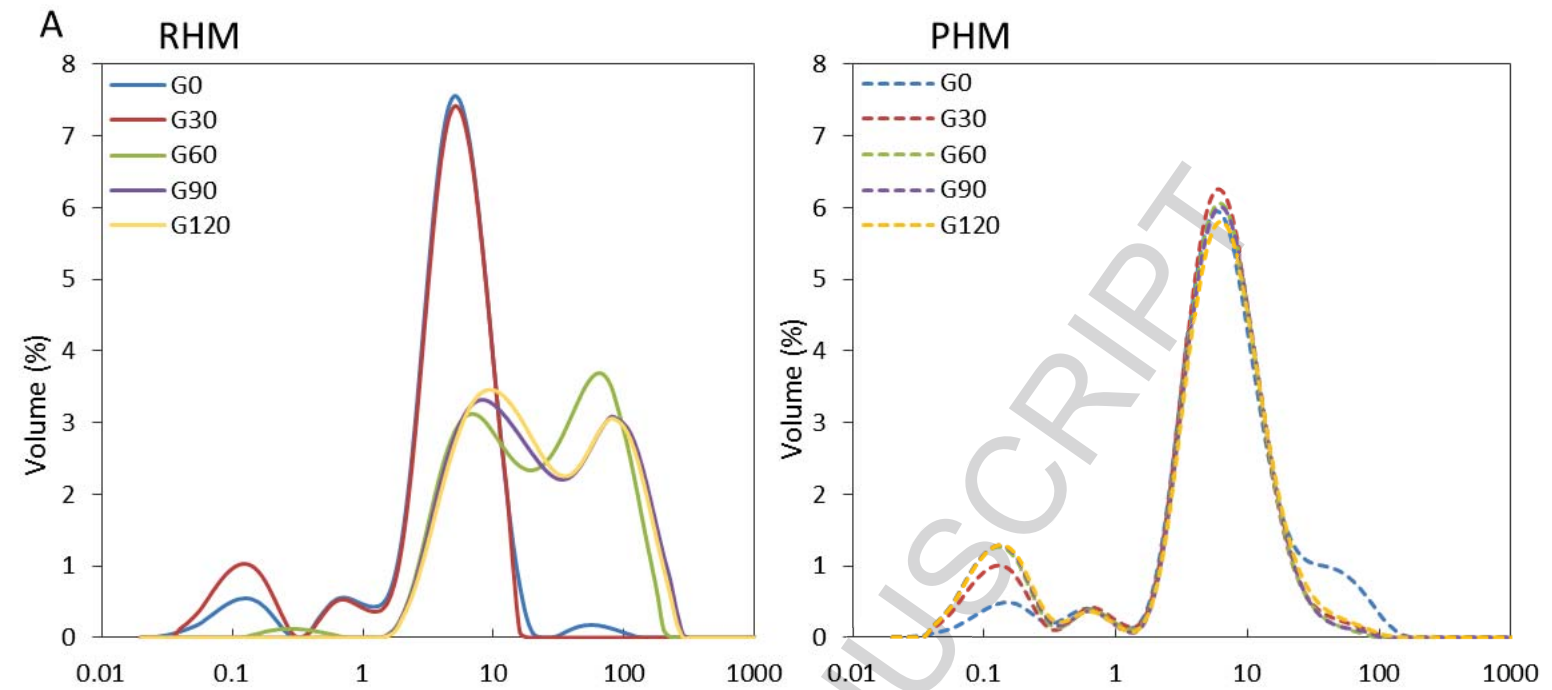

B
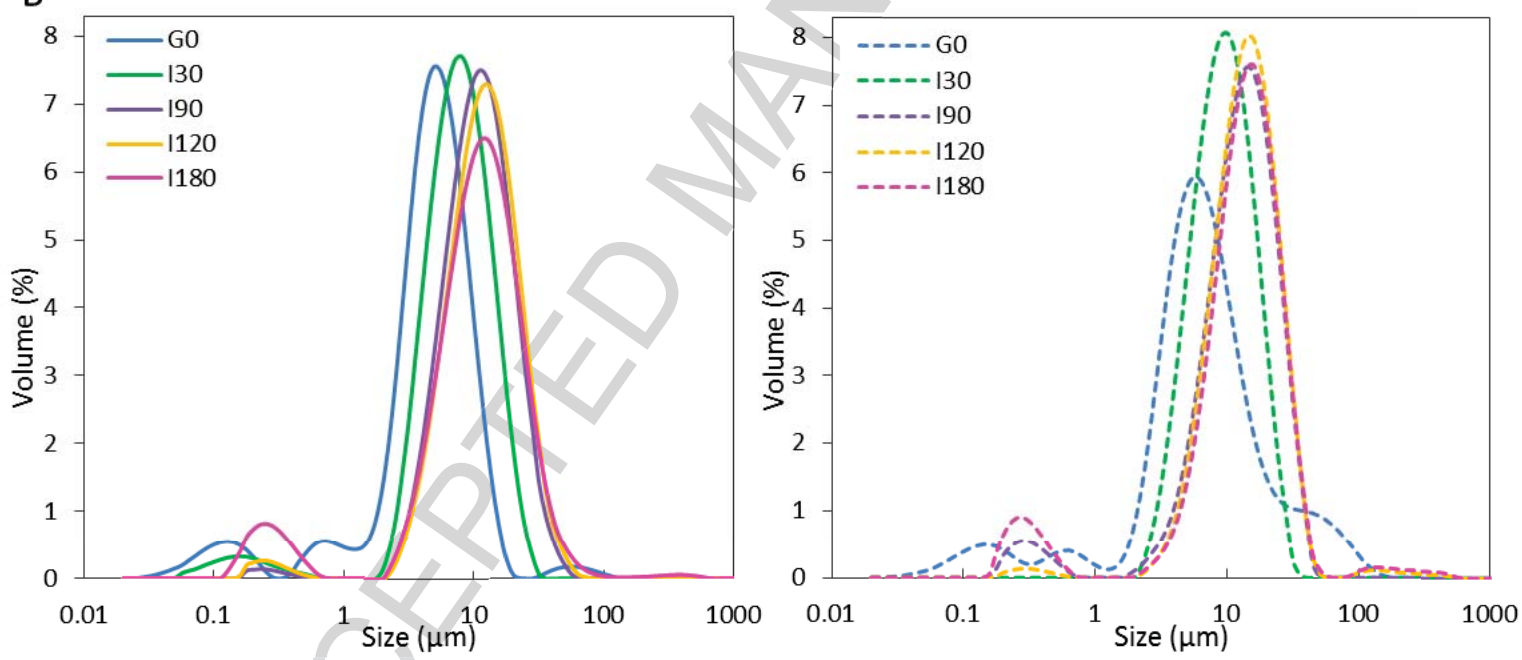
Figure 6
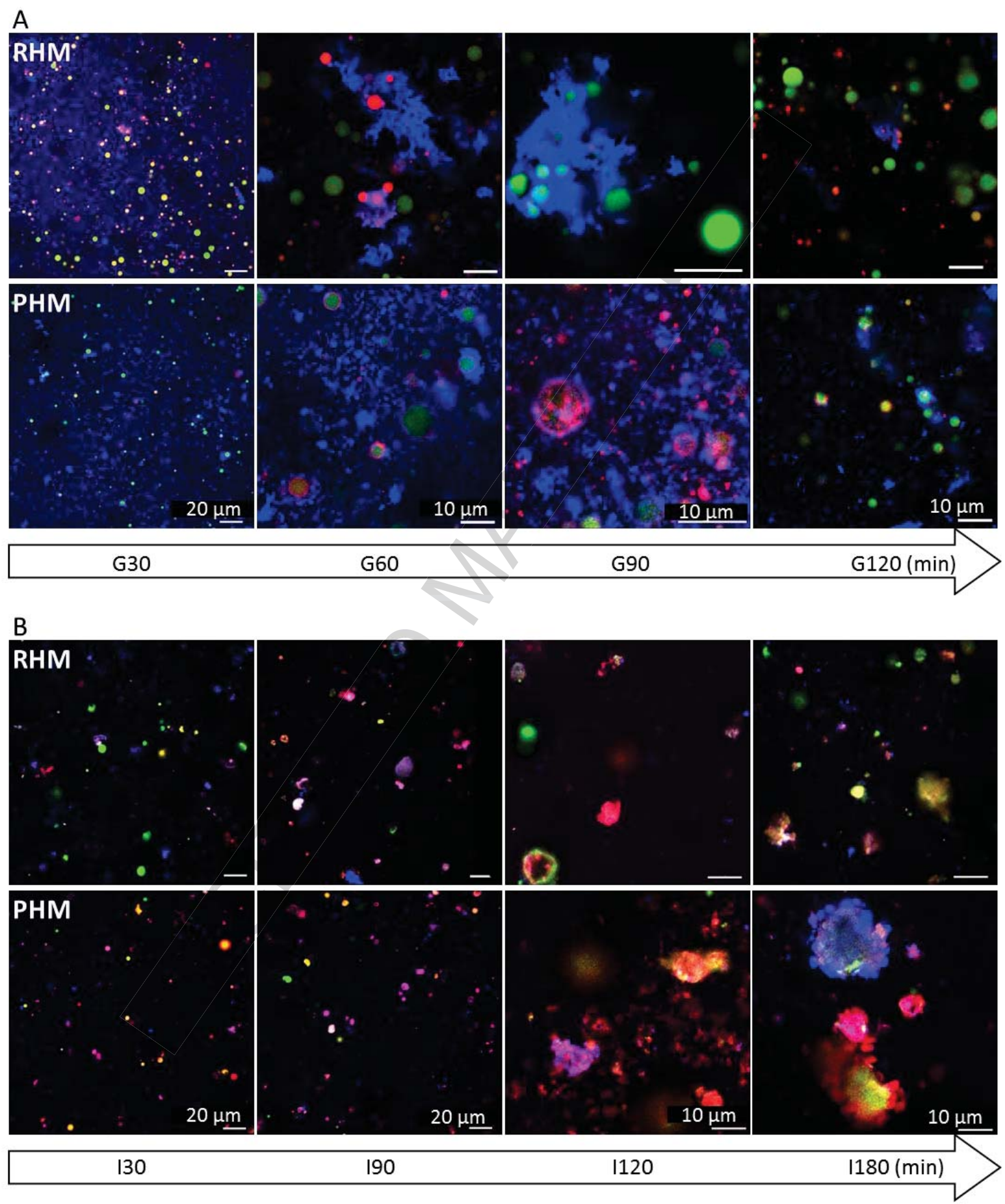


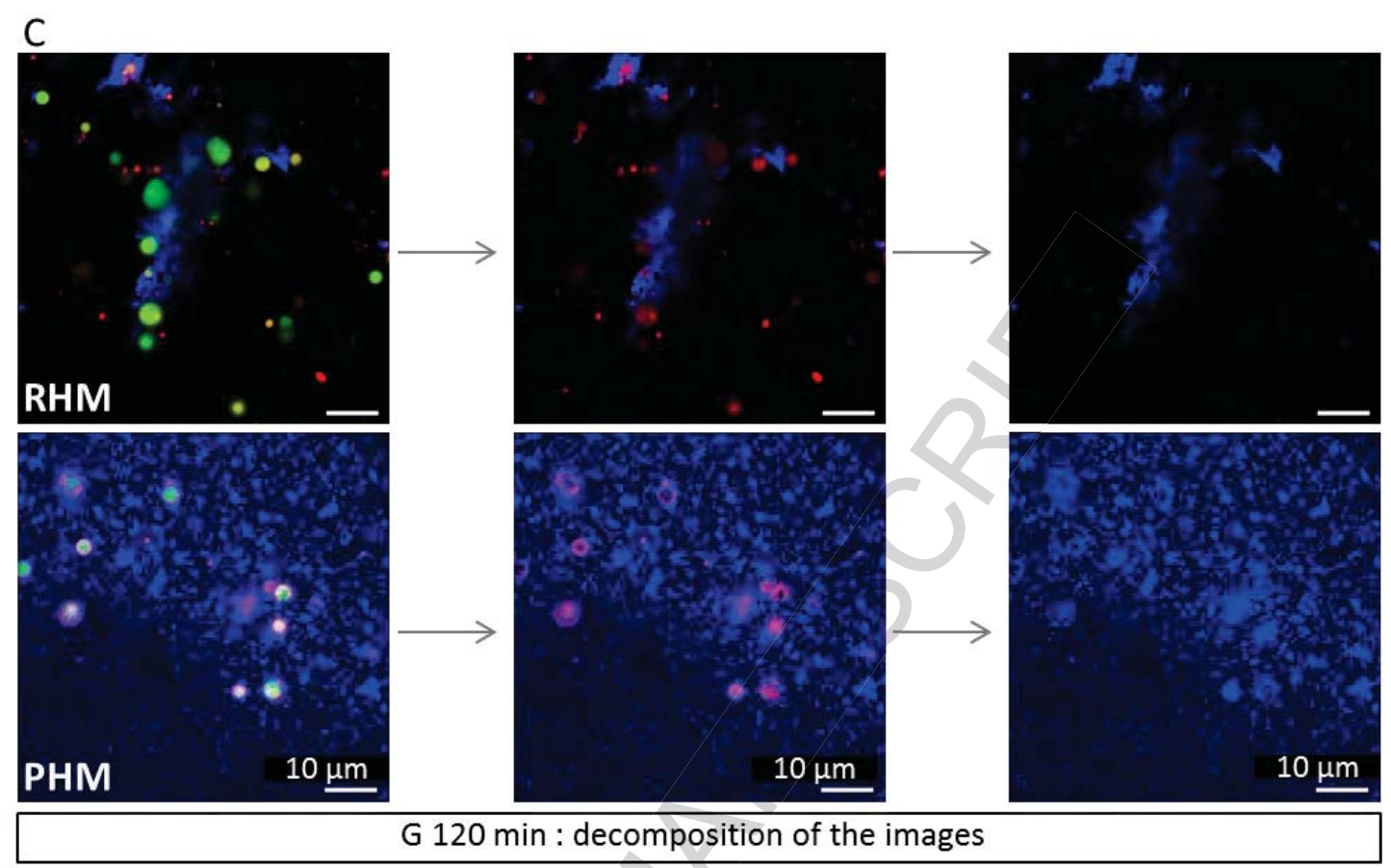


Tables 1 to 3

\section{Table 1}

Gastrointestinal conditions for in vitro dynamic digestion of human milk simulating term conditions

\begin{tabular}{|c|c|c|}
\hline \multicolumn{3}{|l|}{ Gastric conditions $\left(37^{\circ} \mathrm{C}\right)$} \\
\hline SGF & $\mathrm{Na}^{+}$ & $94 \mathrm{mmol} / \mathrm{L}$ \\
\hline \multirow[t]{2}{*}{ (stock solution adjusted at $\mathrm{pH}$ 6.5) } & $\mathrm{K}^{+}$ & $13 \mathrm{mmol} / \mathrm{L}$ \\
\hline & $\mathrm{Cl}^{-}$ & $122 \mathrm{mmol} / \mathrm{L}$ \\
\hline \multirow[t]{2}{*}{ Fasted state / initial conditions } & SGF & \\
\hline & $\mathrm{pH}$ & 2.7 \\
\hline \multirow[t]{2}{*}{ Milk ingested } & Total volume & $100 \mathrm{~mL}$ \\
\hline & Flow rate & $10 \mathrm{~mL} / \mathrm{min}$ from 0 to $10 \mathrm{~min}$ \\
\hline Gastric pH (acidification curve) & \multicolumn{2}{|c|}{$\begin{array}{l}\mathrm{pH}=-0.0155^{*} \mathrm{t}+\text { milk pH } \\
\text { with } t \text { : time after ingestion in min }\end{array}$} \\
\hline \multirow[t]{4}{*}{ SGF + enzymes (RGE) } & Gastric lipase & $19.2 \mathrm{U} / \mathrm{mL}$ \\
\hline & Pepsin & $268 \mathrm{U} / \mathrm{mL}$ \\
\hline & & $1 \mathrm{~mL} / \mathrm{min}$ from 0 to $10 \mathrm{~min}$ \\
\hline & & $0.5 \mathrm{~mL} / \mathrm{min}$ from 10 to $180 \mathrm{~min}$ \\
\hline Gastric emptying & $t_{1 / 2}$ & $47 \mathrm{~min}$ \\
\hline (Elashoff fitting) & $\beta$ & 0.9 \\
\hline \multicolumn{3}{|l|}{ Intestinal conditions $\left(37^{\circ} \mathrm{C}\right)$} \\
\hline SIF & $\mathrm{Na}^{+}$ & $164 \mathrm{mmol} / \mathrm{L}$ \\
\hline \multirow[t]{2}{*}{ (stock solution adjusted at $\mathrm{pH}$ 6.2) } & $\mathrm{K}^{+}$ & $10 \mathrm{mmol} / \mathrm{L}$ \\
\hline & $\mathrm{Ca}^{2+}$ & $119 \mathrm{mmol} / \mathrm{L}$ \\
\hline Intestinal pH & 6.2 & \\
\hline \multirow[t]{2}{*}{ SIF + bile } & Bile salts & $3.1 \mathrm{mmol} / \mathrm{L}$ \\
\hline & Flow rate & $0.5 \mathrm{~mL} / \mathrm{min}$ from 0 to $180 \mathrm{~min}$ \\
\hline \multirow[t]{2}{*}{ SIF + pancreatin } & Pancreatic lipase & $90 \mathrm{U} / \mathrm{mL}$ \\
\hline & Flow rate & $0.25 \mathrm{~mL} / \mathrm{min}$ from 1 to $180 \mathrm{~min}$ \\
\hline Intestinal emptying & $\mathrm{t}_{1 / 2}$ & $200 \min$ \\
\hline (Elashoff fitting) & $\beta$ & 2.2 \\
\hline
\end{tabular}

RGE, rabbit gastric extract; SGF, simulated gastric fluid; SIF, simulated intestinal fluid. 


\section{Table 2}

Amino acid composition of human milk before in vitro digestion

\begin{tabular}{lcc}
\hline Amino acid & Total Amino Acids & Free Amino Acids \\
\hline & \multicolumn{2}{c}{$g / \mathrm{kg}$} \\
Isoleucine & 0.449 & 0.000 \\
Leucine & 0.877 & 0.005 \\
Lysine & 0.611 & 0.001 \\
Methionine & 0.181 & 0.000 \\
Cysteine & 0.186 & 0.007 \\
Phenylalanine & 0.364 & 0.000 \\
Tyrosine & 0.393 & 0.000 \\
Threonine & 0.393 & 0.010 \\
Valine & 0.470 & 0.004 \\
Histidine & 0.210 & 0.002 \\
Glutamic acid & 1.548 & 0.287 \\
Aspartic acid & 0.850 & 0.006 \\
Proline & 0.820 & 0.001 \\
Serine & 0.391 & 0.014 \\
Glycine & 0.201 & 0.008 \\
Alanine & 0.340 & 0.016 \\
Arginine & 0.297 & 0.000 \\
Taurine & - & 0.029 \\
$\alpha$-amino nitrogen & 1.090 & 0.041 \\
Total nitrogen & & \\
\hline
\end{tabular}




\section{Table 3}

Amino acids released from RHM and PHM during intestinal in vitro dynamic digestion simulating term newborn conditions

\begin{tabular}{|c|c|c|c|c|c|c|c|c|c|c|c|c|c|}
\hline \multirow{3}{*}{$\begin{array}{l}\text { Amino } \\
\text { acid }\end{array}$} & \multicolumn{10}{|c|}{ Amino acid released during digestion ( $\% \mathrm{w} / \mathrm{w}$ of total amino acids) } & \multicolumn{3}{|c|}{ Effect of ${ }^{1}$} \\
\hline & \multicolumn{2}{|c|}{ Initial milk } & \multicolumn{2}{|c|}{160} & \multicolumn{2}{|c|}{190} & \multicolumn{2}{|c|}{1120} & \multicolumn{2}{|c|}{1180} & \multirow{2}{*}{$\begin{array}{c}\text { Me } \\
\text { al }\end{array}$} & \multirow{2}{*}{$\begin{array}{c}\mathrm{Tim} \\
\mathrm{e}\end{array}$} & \multirow{2}{*}{$\begin{array}{c}\text { Meal * } \\
\text { Time }\end{array}$} \\
\hline & RHM & PHM & RHM & PHM & RHM & PHM & RHM & PHM & RHM & PHM & & & \\
\hline \multirow[t]{2}{*}{ Isoleucine } & $0 \pm 0$ & $0 \pm 0$ & $\begin{array}{c}8.4 \pm \\
2.3\end{array}$ & $\begin{array}{c}7.7 \pm \\
0.5\end{array}$ & $\begin{array}{c}12.2 \pm \\
2.1\end{array}$ & $\begin{array}{c}13.2 \pm \\
1.5\end{array}$ & $\begin{array}{c}16.5^{\mathrm{b}} \\
0.6^{\mathrm{b}}\end{array}$ & $\begin{array}{c}18.7 \pm \\
0.7^{\mathrm{a}}\end{array}$ & $\begin{array}{c}23.6 \pm \\
5.9\end{array}$ & $\begin{array}{c}28.3 \pm \\
0.9\end{array}$ & NS & $* * *$ & $*$ \\
\hline & $0.5 \pm$ & $0.6 \pm$ & $25.2 \pm$ & $24.6 \pm$ & $30.2 \pm$ & $31.1 \pm$ & $33 \pm$ & $37.3 \pm$ & $47.7 \pm$ & $48.1 \pm$ & & & \\
\hline \multirow[t]{2}{*}{ Leucine } & 0.1 & 0 & 5.4 & 1.2 & 4.5 & 1.6 & 4.4 & 1.9 & 5.6 & 2.4 & NS & $* * *$ & $* * *$ \\
\hline & $0.2 \pm$ & $0.2 \pm$ & $40.4 \pm$ & $38.6 \pm$ & $50.2 \pm$ & $49.4 \pm$ & $56 \pm$ & $59 \pm$ & $82.7 \pm$ & $78.3 \pm$ & & & \\
\hline Lysine & 0.3 & 0.1 & 6.3 & 1.9 & 4.3 & 2.6 & 3.6 & 2.7 & 4.5 & 2.7 & NS & $* * *$ & $* * *$ \\
\hline Methionin & & & $19.6 \pm$ & $13.9 \pm$ & $27.0 \pm$ & $21.0 \pm$ & $33.0 \pm$ & $27.5 \pm$ & $46.7 \pm$ & $39.2 \pm$ & & & \\
\hline \multirow[t]{2}{*}{ e } & $0 \pm 0$ & $0 \pm 0$ & 2.5 & 0.7 & 1.1 & 1.5 & 0.7 & 1 & 2.6 & 2.2 & $*$ & $* * *$ & NS \\
\hline & $\begin{array}{c}3.6 \pm \\
0.1\end{array}$ & $\begin{array}{c}3.7 \pm \\
0\end{array}$ & $\begin{array}{l}9 \pm \\
1.7\end{array}$ & $\begin{array}{c}8.4 \pm \\
0.8\end{array}$ & $\begin{array}{c}10.5 \pm \\
1.1\end{array}$ & $\begin{array}{c}10 \pm \\
0.9\end{array}$ & $\begin{array}{c}12 \pm \\
0.6\end{array}$ & $\begin{array}{c}12.3 \pm \\
1.3\end{array}$ & $\begin{array}{c}18.4 \pm \\
2.6\end{array}$ & $\begin{array}{c}19 \pm \\
0.8\end{array}$ & NS & $* * *$ & $* *$ \\
\hline \multirow[t]{2}{*}{$\begin{array}{l}\text { Phenylalan } \\
\text { ine }\end{array}$} & $0 \pm 0$ & $0 \pm 0$ & $\begin{array}{c}26.4 \pm \\
3.4\end{array}$ & $\begin{array}{c}30.4 \pm \\
1.2\end{array}$ & $\begin{array}{c}35.2 \pm \\
2.7^{b}\end{array}$ & $\begin{array}{c}40.4 \pm \\
1.7^{\mathrm{a}}\end{array}$ & $\begin{array}{c}40.1 \pm \\
2.2^{\mathrm{b}}\end{array}$ & $\begin{array}{c}49.7 \pm \\
2.5^{a}\end{array}$ & $\begin{array}{c}58.4 \pm \\
2.9^{b}\end{array}$ & $\begin{array}{l}63 \pm \\
1.7^{\mathrm{a}}\end{array}$ & NS & $* * *$ & $* * *$ \\
\hline & & & $49.7 \pm$ & $53.0 \pm$ & $58.3 \pm$ & $64.7 \pm$ & $61.2 \pm$ & $75.2 \pm$ & $89.6 \pm$ & $93.1 \pm$ & & & \\
\hline \multirow[t]{2}{*}{ Tyrosine } & $0 \pm 0$ & $0 \pm 0$ & 9.8 & 2.4 & 7.5 & 3.2 & $8.1^{\mathrm{b}}$ & $3.7^{\mathrm{a}}$ & 5.4 & 3.8 & NS & $* * *$ & $* * *$ \\
\hline & $2.6 \pm$ & $2.7 \pm$ & $14.9 \pm$ & $12.7 \pm$ & $17.5 \pm$ & $16.2 \pm$ & $21.5 \pm$ & $20.5 \pm$ & $31.7 \pm$ & $31.7 \pm$ & & & \\
\hline \multirow[t]{2}{*}{ Threonine } & 0.1 & 0 & 2.5 & 0.6 & 1.5 & 0.9 & 0.6 & 1.1 & 4.1 & 1.2 & NS & $* * *$ & NS \\
\hline & $0.8 \pm$ & $1 \pm$ & $12.5 \pm$ & $9.6 \pm$ & $15.3 \pm$ & $13.3 \pm$ & $17.6 \pm$ & $16.9 \pm$ & $25.6 \pm$ & $24.7 \pm$ & & & \\
\hline \multirow[t]{2}{*}{ Valine } & 0.1 & 0.3 & 2.6 & 0.5 & 1.9 & 0.7 & 1 & 0.9 & 3.2 & 1.1 & NS & $* * *$ & $* *$ \\
\hline & $0.9 \pm$ & $1.1 \pm$ & $10.7 \pm$ & $9.5 \pm$ & $14.9 \pm$ & $14 \pm$ & $20 \pm$ & $19.4 \pm$ & $28.8 \pm$ & $30.6 \pm$ & & & \\
\hline Histidine & 1.2 & 1 & 2.9 & 0.8 & 2.1 & 1.9 & 2.5 & 3.4 & 3.8 & 3 & NS & $* * *$ & NS \\
\hline $\begin{array}{l}\text { Glutamic } \\
\text { acid }\end{array}$ & $\begin{array}{c}18.6 \pm \\
0.2\end{array}$ & $\begin{array}{c}18.4 \pm \\
0.4\end{array}$ & $\begin{array}{c}27.9 \pm \\
2.9\end{array}$ & $\begin{array}{c}24.8 \pm \\
1.6\end{array}$ & $\begin{array}{c}30.6 \pm \\
1.2\end{array}$ & $\begin{array}{c}28.1 \pm \\
1.5\end{array}$ & $\begin{array}{c}31.8 \pm \\
1.5\end{array}$ & $\begin{array}{c}32.7 \pm \\
1.3\end{array}$ & $\begin{array}{c}46.8 \pm \\
0.0^{\mathrm{a}}\end{array}$ & $\begin{array}{c}42.7 \pm \\
1.3^{b}\end{array}$ & NS & $* * *$ & $* * *$ \\
\hline acid & $\begin{array}{c}0.8 \pm \\
0.1\end{array}$ & $\begin{array}{c}0.8 \pm \\
0.1\end{array}$ & $\begin{array}{c}10.8 \pm \\
1.6\end{array}$ & $\begin{array}{c}10 \pm \\
0.4\end{array}$ & $\begin{array}{c}13.2 \pm \\
0.5\end{array}$ & $\begin{array}{c}12.4 \pm \\
1.2\end{array}$ & $\begin{array}{c}16.9 \pm \\
2.1\end{array}$ & $\begin{array}{c}15.8 \pm \\
0.8\end{array}$ & $\begin{array}{c}24.8 \pm \\
2.5\end{array}$ & $\begin{array}{c}25 \pm \\
0.7\end{array}$ & NS & $* * *$ & NS \\
\hline Proline & $\begin{array}{c}0.1 \pm \\
0.1 \\
3.5+\end{array}$ & $\begin{array}{c}0.1 \pm \\
0 \\
36+\end{array}$ & $\begin{array}{l}1 \pm \\
0.2 \\
17+\end{array}$ & $\begin{array}{c}0.7 \pm \\
0 \\
14+\end{array}$ & $\begin{array}{c}1.3 \pm \\
0.1 \\
18.9+\end{array}$ & $\begin{array}{c}1 \pm \\
0.1 \\
164\end{array}$ & $\begin{array}{c}1.8 \pm \\
0.1\end{array}$ & $\begin{array}{c}1.3 \pm \\
0 \\
195+\end{array}$ & $\begin{array}{c}2.7 \pm \\
0.4 \\
31 .+\end{array}$ & $\begin{array}{c}2.3 \pm \\
0.2\end{array}$ & $*$ & $* * *$ & NS \\
\hline \multirow[t]{2}{*}{ Serine } & $\begin{array}{c}3.5 \pm \\
0.1\end{array}$ & $\begin{array}{c}3.6 \pm \\
0.1\end{array}$ & $\begin{array}{c}17 \pm \\
2.5\end{array}$ & $\begin{array}{c}14 \pm \\
0.6\end{array}$ & $\begin{array}{c}18.9 \pm \\
1.5\end{array}$ & $\begin{array}{c}16.4 \pm \\
0.8\end{array}$ & $\begin{array}{c}21.1 \pm \\
0.1\end{array}$ & $\begin{array}{c}19.5 \pm \\
0.6\end{array}$ & $\begin{array}{c}31.1 \pm \\
1.1\end{array}$ & $\begin{array}{c}27.4 \pm \\
2.1\end{array}$ & NS & $* * *$ & NS \\
\hline & $3.8 \pm$ & $4.1 \pm$ & $17.6 \pm$ & $16.4 \pm$ & $20.4 \pm$ & $19 \pm$ & $23.6 \pm$ & $22.4 \pm$ & $35.1 \pm$ & $33.2 \pm$ & & & \\
\hline Glycine & 0.4 & 0.1 & 1 & 0.8 & 0.3 & 0.6 & 2 & 0.2 & 0.1 & 0.6 & $* *$ & $* * *$ & NS \\
\hline \multirow[t]{2}{*}{ Alanine } & $\begin{array}{c}4.7 \pm \\
0.3\end{array}$ & $\begin{array}{c}4.9 \pm \\
0.2\end{array}$ & $\begin{array}{c}19 \pm \\
2.5\end{array}$ & $\begin{array}{c}18 \pm \\
0.9\end{array}$ & $\begin{array}{c}23 \pm \\
1.4\end{array}$ & $\begin{array}{c}22.7 \pm \\
1.2\end{array}$ & $\begin{array}{c}27.4 \pm \\
0.4\end{array}$ & $\begin{array}{c}28.2 \pm \\
1.2\end{array}$ & $\begin{array}{c}40.3 \pm \\
3.5\end{array}$ & $\begin{array}{c}41.3 \pm \\
1.2\end{array}$ & NS & $* * *$ & NS \\
\hline & & & $65 \pm$ & $67.5 \pm$ & $74.1 \pm$ & $78.2 \pm$ & $77.8 \pm$ & $88.1 \pm$ & 113.6 & 111.6 & & & \\
\hline Arginine & $0 \pm 0$ & $0 \pm 0$ & 13.5 & 3.9 & 9.1 & 4.8 & 7.4 & 4.6 & \pm 5.9 & \pm 3.3 & NS & $* * *$ & $* * *$ \\
\hline$\alpha$-amino & $3.5 \pm$ & $3.5 \pm$ & $24.3 \pm$ & $22.9 \pm$ & $28.9 \pm$ & $28.2 \pm$ & $32.1 \pm$ & $33.7 \pm$ & $47.0 \pm$ & $45.3 \pm$ & & & \\
\hline nitrogen & 0.2 & 0.1 & 4.1 & 1.1 & 2.7 & 1.4 & 1.6 & 1.5 & 3.1 & 1.1 & NS & $* * *$ & $*$ \\
\hline
\end{tabular}

${ }^{1}$ Statistics were conducted on data from 160 to 1180 . Statistical significance: $p<0.001(* * *) ; p<0.01$ $\left({ }^{* *}\right) ; p<0.05\left(^{*}\right) ; p>0.1$ (NS). When there was a significant interaction, multiple comparisons of means were conducted. Data having a different letter within the same row and at the same time point significantly differed. 
Highlights

- Set up of an in vitro dynamic digestion model for term newborn

- Holder pasteurization of human milk induces protein aggregation

- Protein hydrolysis is modulated by Holder pasteurization

- Thermo-inactivation of endogenous lipases affects the lipolysis of human milk

- Gastric disintegration of human milk is affected by Holder pasteurization 